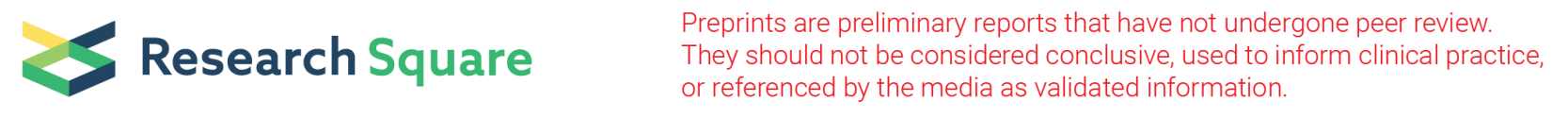

\title{
How to improve participant compliance and retention in clinical trials $₫ A$ Scoping Review
}

Mingkun Yu

Beijing University of Chinese Medicine

Ziyi Lin

Beijing University of Chinese Medicine

Changhao Liang

Beijing University of Chinese Medicine

Chengze Li

Binzhou Medical University

Zhijia Zhang

Beijing University of Chinese Medicine

Kexin Liu

Beijing University of Chinese Medicine

Xun Li

Beijing University of Chinese Medicine

Jianping Liu

Beijing University of Chinese Medicine

Yutong Fei ( $\nabla$ feiyt@bucm.edu.cn)

Beijing University of Chinese Medicine https://orcid.org/0000-0003-3051-0581

Research article

Keywords: factors, strategies, compliance, retention, scoping review

Posted Date: November 20th, 2020

DOI: https://doi.org/10.21203/rs.3.rs-52627/v2

License: @ (1) This work is licensed under a Creative Commons Attribution 4.0 International License. Read Full License 


\section{Abstract}

Background: The reliability of results can be compromised when subsets of participants who remain on a study differ from those who drop out. Although recent studies have investigated strategies for improving compliance and retention, there has been very little investigation of process factors, regardless of the type of literature and the publication date. factors that may influence how and why compliance and retention may be successful (or not).

Aim: To identify process factors that may influence participant compliance and retention in clinical trials, and potential strategies to improve the compliance and retention, from published studies, grey literature, and the reference lists of included articles to facilitate future design and implementation of trials.

Methods : Six databases and two clinical trial registries were searched on November 29, 2019. Surveys, interviews, retrospective data analyses, theoretical research, reviews and clinical studies aiming at investigating factors and potential strategies were included. Data synthesis followed an iterative process to develop a list of process factors and potential retention strategies.Results were presented mainly as texts, including visualization using word cloud, and descriptive data.

Results: 182 publications were included in this review, composed of 58 retrospective reflection of RCTs based on 1,132 clinical trials with 177804 participants, 27 implementation researches, 22 theoretical researches, 20 interviews, 18 surveys, 17 randomized controlled trials, 8 literature reviews, 5 systematic review and meta analysis, 3 mixed methods researches, 2 case report, 1 meta-ethnographic synthesis and 1 cohort study. We identified 70 process factors that may affect the compliance and retention. The most commonly addressed factors were age, education, economy, trust in clinical trials, supporting from surrounding people, safety concerns and effectiveness. We found 42 potential strategies to improve compliance and retention. Strategies reported most frequently were that researchers should pay attention to the changes on participants' psychological condition, try their best to build good relationships, provide some compensation and educate the participants about compliance and retention .

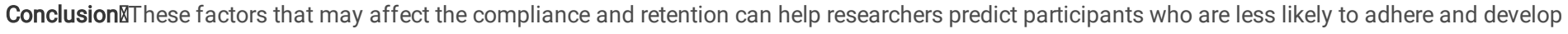
screening tools to find efficiently their suitable participants. These potential strategies that may improve the compliance and retention.

\section{Background}

The compliance and retention of participants with clinical trial protocols is defined as the degree of participation according to the prescribed drug dose, medication, timeliness of response, retention, and careful treatment according to the doctor's request ${ }^{[1]}$. The reliability of results can be compromised when subsets of participants who enroll or remain on a study are differ from those who choose not to take part or subsequently drop out ${ }^{[2]}$. Difficulties in achieving the compliance and retention of participants in randomized controlled trials (RCTs) are well documented ${ }^{[3]}$, and many clinical trials are stopped or extended due to issues about compliance and retention ${ }^{[4]}$. Directors of UK clinical trials units have identified "research into methods to boost recruitment in trials" and "methods to minimise attrition" as the top two priorities for trials methodology research ${ }^{[3,5]}$.

Clinical trial researchers often focus more on the trial design, paying less attention to participant compliance and retention ${ }^{[6]}$. Although there is extensive information in the scientific literature on compliance and retention of participants in clinical trials, few researchers have summarized this systematically in China ${ }^{[6]}$. There are numerous factors that may affect compliance and retention and also a range of potential strategies for improving compliance and retention in clinical trials. Previous studies have suggested that a greater understanding of the factors that influence trial participation could help to provide solutions for improving compliance and retention ${ }^{[7]}$. Furthermore, findings from studies that successfully predict which participants are likely to comply with trial protocols could also be used to develop screening tools to enable researchers when planning trial recruitment to more efficiently identify participants who would be less likely to drop out ${ }^{[8]}$.

The purpose of this comprehensive scoping reviewing is to investigate the process factors that influence participant compliance and retention in clinical trials, and potential strategies to improve compliance and retention, from published studies, to facilitate future improvements in the design and implementation of clinical trials.

\section{Methods}

\section{Protocol}

Although PROSPERO rejected the registration of the protocol, all research processes were carried out according to a pre-made protocol

\section{Search strategy}

Literature searches were carried out in six databases (including Chinese databases) and two clinical trial registries before 2019-11-29: PubMed, Cochrane Library, Embase, CNKI, VIP and Wanfang Databases; clinical trials.gov and Chinese clinical trial registries. Search terms and strategies are provided in Appendix A. We also searched manually the grey literature that were not peer reviewed and investigated the reference lists of included articles and existing systematic reviews. No language or publication type restrictions were applied. The meeting abstracts were not included.

\section{Eligibility criteria and selection process}

Eligible articles were those which aimed to explore process factors that influence compliance and retention and/or reported potential strategies for improving compliance and retention, including theoretical research, descriptive epidemiological studies (cross-sectional surveys), systematic reviews and all types of 
clinical studies, such as randomized controlled trials (RCTs), non-randomized clinical controlled trials (CCTs), cohort studies, case-control studies, case series and case reports.

Noteexpress was used for the management of articles. Firstly, titles and abstracts were retrieved and screened independently by two reviewers (MK and $\mathrm{CH}$ ). Articles were included for full text screening as long as there was at least one reviewer who included them at this stage. Then duplicates were removed. Fulltext articles of those that past title/abstract screening were retrieved and further screened by paired independent reviewers ( $\mathrm{MK}$ and $\mathrm{CH}$ ), too. Any disagreements were resolved through discussion or arbitrated by the senior author (Fei YT), if necessary. The reasons for exclusion were recorded and presented(As shown in Fig 1).

\section{Data extraction and synthesis}

Data were extracted from each study independently by three pairs of trained reviewers (two reviewers in each group) using a pre-designed pilot-tested topic collection form and performed two-person checks. The extracted data included: article and author information(publication date, funding, language, country); the information of study(disease, the purpose of article, study design, sample, number of study sites, topic source (for Secondary studies only)); process factors that may influence compliance; and potential strategies for improving compliance. Any disagreements were resolved through discussion or arbitrated by the senior author (Fei YT), if necessary. When new factors and strategies were identified, group discussion were conducted. When more than $2 / 3$ of all members of the extraction team (MK Yu, ZY Lin, CH Liang, ZJ Zhang, KX Liu and CZ Li) agreed, the new factor or approach was added in the list. The process of topic extraction was used to iteratively develop a list of the process factors and potential strategies that may influence compliance and retention. The extracted topics were categorized and induced to investigate which are the key process factors and strategies. No test of statistical significance was performed.

Word cloud technique (https://www.weiciyun.com/) was used to identify the major concepts that were presented in the included papers that were relevant to compliance and retention. The font size of the concept (words or phrases) in the word cloud picture is positively correlated to the frequency of concept.

\section{Definition of key information}

We defined compliance and retention in RCTs as the ability to avoid loss of follow-up visits, including loss of contact with the research team (including subsequent loss of follow-up during the study and failure of the research team to re-establish contact), non-compliance with medication and attendance appointments.

Descriptive analysis was defined as: researchers use the statistics represented by various topic to conduct single-factor analysis (such as mean, percentage, etc.) to find the central tendency and dispersion trend of these topic.

Implementation research can be defined as scientific research that verifies that interventions can be applied to clinics and communities. The purpose is to improve the prognosis of patients and benefit the health of the population.In our study, it not only include retrospective research, theoretical research, interviews, surveys, randomized controlled trials, literature reviews, systematic review and meta analysis, mixed methods research, case report and cohort study.

Retrospective reflection of RCTs can be defined as the researchers reviewed the randomized controlled studies conducted in the past to obtain the process factors and improvement strategies that affect the subject compliance and retention.

\section{Results}

We identified a total of 46179 publications through the searches, and a total of 182 publications ${ }^{[6,9-189]}$ met the inclusion criteria (Figure 1 ).

\section{Study characteristics}

The 182 publications included 58 retrospective reflection of RCTs(177804 participants) , 27 implementation researches, 22 theoretical researches, 20 interviews, 18 surveys, 17 randomized controlled trials, 8 literature reviews, 5 systematic review and meta analysis, 3 mixed methods researches, 2 case report, 1 meta-ethnographic synthesis and 1 cohort study (Appendix table 1). The compliance and retention of participants in trials for human immunodeficiency virus(HIV), cancer, diabetes, asthma, hypertension, parkinson, alcohol addiction, cocaine dependence, etc were identified and included. Researchers, pregnant women, minor, adolescents, seniors, and healthcare providers were investigated. 124 publications published in English, 56 published in Chinese, and 1 published in German.

Included studies were published between 1982 and 2019, with the number of publications increasing across time (Fig. 2). Studies were published across 21 countries, with the majority of first authors being located in the United States( $n=77$ studies), China ( $n=58$ studies) or England ( $n=17$ studies) .

\section{Process factors that may influence compliance and retention}

70 key factors affecting compliance and retention, which grouped into individual, environment, disease, protocol and investigator aspects (Table 1), were finally identified. The factors with highest frequencies were: age(55.4\%), education(43.9\%), economic(41.8\%), investigators' skills on communication(41.2\%), the adequacy of informed consent(39.5\%), gender(39.0\%), support from personal social relationship(39.0\%), trust for the trials(36.2\%), attitude(investigator's attitude towards research and patients)(34.0\%) and safety concerns(32.9\%).

Potential strategies to improve compliance and retention 
42 key themes of potential strategies were eventually included. According the scenarios for actual clinical research, the included potential strategies were divided into three phases: protocol design, recruitment and informed consent, trial implementation period (Table 2).The potential strategies with highest frequencies were:(1)Researchers should pay attention to the changes on participants' psychological and building good relationships with participant(41.2\%); (2)Money, gifts and other compensation can be provided(36.8\%); (3)Researchers should carry out the education about compliance and retention during the study (including the knowledge of diseases, psychological and medication, trained in the broader context of medical ethics, cultural training)(35.7\%); (4)Researchers should give full informed consent to the participant(safety concerns, effect, study protocol, the time they may take,etc)(29.6\%);(5) Online reminder (phone, email, etc) should be provided(29.6\%).

\section{The analysis of process factors and improvement strategies based on diseases and population}

According to the prognosis and course of the diseases, we divided the diseases into chronic non-fatal, chronic fetal, acute non-fetal, acute fetal ,and unclear. The population was divided into adults, women, juveniles, seniors, pregnant women, special population, minority, homosexuality, healthcare providers, or Ebola front-line workers and "not reported". The division of the population is based on the original article. The process factors and improvement strategies were analyzed based on diseases and population(Shown in Figure 4-7). Data of different groups were not overlapped. We could find that process factors and improvement strategies varied in different populations. At the same time, Appendix figures 1-10 showed the process factors and improvement strategies under the combination of different diseases and populations.

In adults, the top five process factors were age(47), informed consent(40), education(35), gender(34), economic(33); the top five improvement strategies were expanding the channels of recruitment(28), carrying out education(20), recording 3-4 contact information of participants or their family(20), online data collection(20), paying attention to participants' psychological condition(19).

In women, the top five process factors were support from surrounding people(10), researchers' attitude(10), age(9), economic(8), education(7), work commitment(7), time(7), safety concerns(7); the top five improvement strategies were paying attention to participants' psychological(11), full implementation of informed consent(7), carrying out education(7), flexible study time and location(7), money, gifts and other compensation(6).

In juveniles, the top five process factors were support from surrounding people(10), age(9), economic(6), race(6), culture(6), traffic(6), compensation(6), researchers' skills on communication(6), researchers' attitude(6); the top five improvement strategies were money, gifts and other compensation(10), providing online reminder(8), paying attention to participants' psychological condition(6), establishing the table of follow-up(6), flexible study time and location(6).

In seniors, the top five process factors were age(5), gender(5), special psychological characteristics(4), Informed consent(3), support from surrounding people(3); the top four improvement strategies were expanding the channels of recruitment(3), fixed researchers and healers(2), handle adverse reactions timely(2), flexible study time and location(2).

In pregnant women, the top two process factors were frequency of inspection(2), compensation(2); the top five improvement strategies were money, gifts and other compensation(3), flexible study time and location(3), recruiting full-time researchers(2), expanding the channels of recruitment(2), providing online reminder(2), carrying out education(2), recording 3-4 contact information of participants or their family(2), fixed researchers and healers(2).

In the special population with mental and physical disorders, the top five process factors were economic(3), gender(2), education(2), age(2), special psychological characteristics(2), race(2), language(2), mobility(2), traffic(2), support from private doctors(2); the top five improvement strategies were training researchers(1), improving the screening table based on factors(1), reducing the frequency of harmful inspection(1), full implementation of informed consent(1), expanding the channels of recruitment(1), paying attention to participants' psychological condition(1), money, gifts and other compensation(1), providing online reminder(1), recording 3-4 contact information of participants or their family(1), flexible study time and location(1).

In minority, the top five process factors were economic(1), gender(1), trust for the trial(1), special psychological characteristics(1), culture(1), language(1), researchers' skills on communication(1), researchers' attitude(1), researchers' experience(1), the mastery of the study protocol(1), the education for participants(1); the top five improvement strategies were training researchers(1), pre-compliance and retention assessment(1), providing online reminder(1), researchers should adhere to the basic ethical principles(1).

In homosexuality population, the top five process factors were: education(1), economic(1), gender(1), work commitment(1), lost contact(1), race(1), culture(1), language(1), researchers' skills on communication(1), researcher' attitude(1), the relationship between researchers and participants(1); the top five improvement strategies were: paying attention to participants' psychological condition(1), money, gifts and other compensation(1), recording 3-4 contact information of participants or their family(1), establishing the table of follow-up(1), flexible study time and location(1).

In healthcare providers, or Ebola front-line workers, the top five process factors were age(1), economic(1), gender(1), work commitment(1), interest in the trial(1), lost contact(1), self-efficacy(1), religious(1), researchers' experience(1), the mastery of the study protocol(1) \the top five improvement strategies were develop simple and convenient design(1), training researchers(1), recruiting full-time researchers(1), paying attention to participants' psychological condition(1), money, gifts and other compensation(1), recording 3-4 contact information of participants or their family(1), flexible study time and location(1).

In some studies that did not report specific populations, the top four process factors were: the relationship between researchers and participants(35), researchers' skills on communication(33), frequency of inspection(31), age(28), trust for the trial(28); the top five improvement strategies were: paying attention to participants' psychological condition(34), full implementation of informed consent(30), money, gifts and other compensation(28), carrying out education(25), pre-compliance and retention assessment(23). 
In acute fatal diseases, the top four process factors were: age(4), education(3), gender(3), patient's condition(3); the top four improvement strategies were developing simple and convenient design(2), expanding the channels of recruitment(2), paying attention to participants' psychological condition(2), online data collection(2).

In acute non-fatal diseases, the top three process factors were gender(5), trust for the trial(4), age(4);the top five improvement strategies were money, gifts and other compensation(3), paying attention to participants' psychological condition(3), handle adverse reactions timely(3), the drug package should be accompanied by detailed information(3), online data collection(3).

In chronic fatal diseases, the top five process factors were age(31), education(21), gender(20), informed consent(18), researchers' skills on communication(18); the top five improvement strategies were paying attention to participants' psychological condition(18), expanding the channels of recruitment(17), carrying out education(15), providing online reminder(14), recording 3-4 contact information of participants or their family(13).

In chronic non-fatal diseases, the top five process factors were age(37), economic(30), education(27), gender(27), researchers' skills on communication(25), support from surrounding people(25); the top five improvement strategies were money, gifts and other compensation(26), paying attention to participants' psychological(23), providing online reminder(22), carrying out education(21), expanding the channels of recruitment(19).

In some studies with unclear diseases, the top five process factors were researchers' skills on communication(30), education(27), age(26), trust for the trial(26), support from surrounding people(26); the top five improvement strategies were paying attention to participants' psychological condition(29), carrying out education(26), money, gifts and other compensation(24), full implementation of informed consent(22), establishing the table of follow-up(20).

\section{Discussion}

\section{Summary of results}

182 publications were included in this review. We reviewed 58 retrospective researches from RCT based on 1,132 clinical trials with 177804 participants, and identified 70 factors, which were grouped into individual, disease, environment, protocol and investigators aspects, influencing participant compliance and retention; and 42 potential strategies, which could be adopted in three phases (protocol design, recruitment and informed consent, the trial implementation period) to improve compliance and retention. There were unique factors and strategies among different population and disease conditions. Most prevalent factors were participant age, gender, education, economic condition, researchers' communication skill, support from surrounding people and trust to the trial. Most proposed strategies were paying attention to participants' phycological condition, giving gifts or compensation, recording 3-4 contacts, expanding recruitment channels, carrying out participant education, flexible time and location and providing online reminder.

\section{Strengths And Limitations}

In past systematic map of digital tools for recruitment and retention we found that process factors were hardly studied ${ }^{[191]}$, even though these may be important for understanding how and why strategies for improving retention work (or do not work). As far as we know, this is the first attempt to summarize the factors and the potential strategies of compliance and retention, regardless of the type of literature and the publication date. The results were from 177804 people (including pregnant women, minor, the elderly, college students, addicts, etc), 62 diseases (including cancer, HIV, cancer, diabetes, respiratory diseases, cardiovascular diseases, hypertension, parkinson, alcohol addiction, cocaine dependence, etc) and 22 countries (high income: the United States, Korea, Canada, Spain, etc; middle income: China, India, etc; lower income: Gambia)(Appendix table 1). The findings are more universal. The impact of different process factors and improvement strategies may be different in different diseases or populations. However, most previous studies have ignored them.

Compared with previous literature ${ }^{[63,65]}$, we analyzed the process factors and improvement strategies according to the characteristics of different diseases and populations to show their respective special factors and strategies. Scoping review methods and word cloud were used in our study. We used systematic and extensive approach to identify and analyze literature. However,the diverse factors and potential strategies reported in the included studies make it difficult to draw an overall and exact conclusion. The included studies were mainly reflections of conducting RCTs. At present, there was still a lack of risk bias evaluation tools for these types of research. So various types of study design limit our assessment of the risk of bias for included articles. ${ }^{\text {[191] }}$

\section{Relationship with previous relevant works}

The types of previous relevant works included systematic review(5) and traditional literature review(8). Most studies are only conducted on specific diseases(HIV, stroke, schizophrenia, smoke, Cataract, Amyotrophic lateral sclerosis, Arthritis, Alzheimer). The purpose of systematic review and meta analysis was to test the effect of potential strategies from some trials to improve the compliance and retention. The design of compliance and retention studies includes observational studies, cohort studies, and randomized controlled trials, etc. Variations in research design and lack of overlapping outcome variables often lead to failure to complete systematic reviews. ${ }^{[192]}$ But the influencing factors of compliance and retention and theoretical perspectives were not provided in depth. The traditional literature review described the factors and potential strategies from other researches. But it is possible to miss some articles because the lack of systematic search. Compared with previous studies, the factors and potential strategies provided in our study are more comprehensive. We provide factors and methods for different diseases, populations and interventions. Their conclusions were summarized and analyzed in our study by scoping review. By scoping review, we systematically searched, selected, and integrated existing information to draw a picture of the status and association of compliance and retention studies. In addition, their conclusions were classified and displayed from these studies according to the different stages and characteristics of clinical trials.

\section{Implications for practice and research}


The factors identified in our study can help researchers predict participants who are less likely to adhere, and develop screening tools to find efficiently their suitable participants. The better researchers understand these factors, the better it will be to improve participant compliance and retention. The potential strategies for improving compliance and retention we found were generally targeting at the factors we identified. However, the factors were not sufficiently covered by the potential strategies we found. There is a need to develop more comprehensive potential strategies to address the factors we already know.

In addition, the disagreement between studies demonstrated that these factors may play different roles in different studies, sometimes positive, sometimes negative, and sometimes no effect. For example, age was a commonly reported factor influencing compliance and retention in the clinical trials, but it was reported that young people may increase or decrease participant compliance and retention. Therefore, most of the identified factors have been presented in a neutral form in our study. Researchers should well-thought-out according to their specific trial context.

The potential strategies mostly mentioned were that researchers should pay attention to the changes on participants' psychological condition, and try their best to build good relationships. Providing compensation (such as gifts, money, postcard) and educating the participants about compliance and retention during the study (including the knowledge of diseases, psychology and medication), full implementation of informed consent and reminding participants online (phone, email, etc) were also mentioned by many. Potential strategies still need to be comprehensively developed. Furthermore, adopting potential strategies are often resource demanding. Researchers need to realize this and try to prepare it when planning the trial. Cost-benefit analysis may be required.

In different population, women, juveniles, seniors, and people with physical or mental disorders may need more support from external conditions.In addition to objective conditions such as age and economics, they also need the support of people around them and researchers. Their psychology may be more sensitive and need to be paid more attention. They may also need more flexible research time and location in order to better complete the research. Culture, language and the efforts of researchers play an important role in influencing the compliance and retention of minorities. In different diseases, the severity of the diseases had an important effect in the compliance and retention of patient in acute fatal diseases. Patients who are overly ill may not tolerate the treatment so that they may withdraw or become less adherent. The trust for the trials was very important for acute non-fatal diseases. In chronic non-fatal and fetal diseases, the prolonged course of the diseases may cause them to need more support from people around them and researchers. In chronic fatal diseases, full informed consent is essential.

Qualitative methods could be used to make an in-depth exploration to the factors and potential strategies in the future research. More researches are also needed to find effective potential strategies to encourage the participants to return the sites for follow-up. Implementation research (including, but not limited to, randomized controlled trials) can be used to verify the effectiveness of these included potential strategies by evaluating specific outcomes, such as compliance and retention rate, compliance and retention improvement rate, retention rate, etc.

\section{Conclusions}

We identified 70 factors, which were grouped into individual, disease, environment, protocol and investigators aspects, influencing participant compliance and retention; and 42 potential strategies, which could be adopted in three phases (protocol design, recruitment and informed consent, the trial implementation period) to improve compliance and retention. The process factors and improvement strategies of different diseases and populations are specific. Women, adolescents, seniors, and patients with mental or physical disorders may need more support from relatives, friends and researchers than adults. The long process of treatment also requires them to give more support to patients with chronic diseases. These factors can help researchers predict participants who are less likely to adhere and develop screening tools to find efficiently their suitable participants. Before using these potential strategies, researchers should well-thought-out according to budget, the range of diseases, population, the design of their research and their usual follow-up procedures.

\section{Abbreviations}

UK:United Kingdom; CNKI:China national knowledge infrastructure; VIP:VIP for China Science and Technology Journal Database; RCT: Randomized controlled trial; HIV: Human immunodeficiency virus.

\section{Declarations}

Ethics approval and consent to participate:Not applicable

Consent for publication:Not applicable

Availability of data and materials:All data and materials can be obtained from the corresponding author.

Competing interests: There are no conflicts of interest in this study.

Funding: This work was supported by the National Natural Science Foundation project (No. 81830115). The funding body -National Natural Science Foundation project is a public funding. It does not play role in the design of the study and collection, analysis, and interpretation of data and in writing the manuscript.

Author contributions: YT F and MK Y conceived and designed the review. MK Y and YT Fei drafted the protocol. MK Y, ZY L CH L, CZ L, ZJ Z, KX L were responsible for the searching, screening and selecting studies. They all participated in data extraction and assessed study quality. MK $Y$ and $C Z L$ made forms and pictures and performed the statistical analysis. JP L, YT F and X L were all involved in critically revising the manuscript. All authors have read and approved the final manuscript to submit. All authors approved the final version of the article, including the authorship list. 
Acknowledgements: We are grateful to Dr. Geoff Frampton and Ms. Jin Xuejing for their contributions to the language and content of the article in the manuscript.

\section{References}

[1]BOUDES P .Drug compliance in therapeutic trials:a review [ J]: Control Clin T rials,1998, 19(3):257-268.

[2]Karlson CW, Rapoff MA. Attrition in randomized controlled trials for pediatric chronic conditions. J Pediatr Psychol. 2009;34(7):782-93.

[3]McDonald AM, Knight RC, Campbell MK, et al. What influences recruitment to randomised controlled trials? A review of trials funded by two UK funding agencies. Trials. 2006;7(1):9.

[4]Tooher RL, Middleton PF, Crowther CA. A thematic analysis of factors influencing recruitment to maternal and perinatal trials. BMC Pregnancy Childbirth. 2008;8(100967799):36.

[5]Tudur Smith C, Hickey H, Clarke M, Blazeby J, Williamson P. The trials methodological research agenda: results from a priority setting exercise. Trials 2014;15:32.

[6]MK Yu; Y Xu; RX Hu. Characteristics of the methodological studies on patient compliance in clinical trials in China. Chin J Evid-Based Med. 2019,19(06):708-714.

[7] Brintnall-Karabelas J, Sung S, Cadman ME, Squires C, Whorton K. Improving recruitment in clinical trials: why eligible participants decline. J Empir Res Hum Res Ethics. 2011;6(1):69

[8]Driscoll K, Killian M, Johnson S, Silverstein J, Deeb L. Predictors of study completion and withdrawal in a randomized clinical trial of a pediatric diabetes adherence intervention. Contemp Clin Trials. 2009; 30(101242342):212-220.

[9]Soumya J. Niranjan ,Raegan W. Durant,Jennifer A. Wenzel,etc. Training Needs of Clinical and Research Professionals to Optimize Minority Recruitment and Retention in Cancer Clinical Trials[J].J Canc Educ,2019,34:26-34.

[10]Eleanor Ladd Schneider Leavens, Elise Marie Stevens, Emma Irene Brett, Neil Molina, Thad Ryan Leffingwell, Theodore Lee Wagener.Use of Rideshare Services to Increase Participant Recruitment and Retention in Research: Participant Perspectives[J].JOURNAL OF MEDICAL INTERNET RESEARCH,2019,21(4):e11166.

[11]Laura A. Novak,Bradley E. Belsher,Michael C. Freed,Phoebe K. McCutchan,Xian Liu,Daniel P. Evatt,Terri Tanielian,Robert M. Bray,Charles C. Engel. Impact of financial reimbursement on retention rates in military clinical trial research: A natural experiment within a multi-site randomized effectiveness trial with active duty service members[J]. Contemporary Clinical Trials Communications,2019,15.

[12]Zhou Q, Ratcliffe S J, Grady C, et al. Cancer Clinical Trial Patient-Participants' Perceptions about Provider Communication and Dropout Intentions[J]. AJOB empirical bioethics, 2019, 10(3): 190-200.

[13]Wisk LE, Nelson EB, Magane KM,Eliza B Nelson, Kara M Magane, Elissa R Weitzman.Clinical Trial Recruitment and Retention of College Students with Type 1 Diabetes via Social Media: An Implementation Case Study[J].Journal of Diabetes Science and Technology,2019,13(3):445-456. doi:

$10.1177 / 1932296819839503$.

[14]JS Liang, KW Huang. Effects of drug clinical trial programs on subject compliance and management strategies [J]. China Health Industry, 2019, 16 (11): 89-91. DOI: 10.16659 / j.cnki.1672 -5654.2019.11.089.

[15] Henshall C, Narendran P, Andrews R C, et al. Qualitative study of barriers to clinical trial retention in adults with recently diagnosed type 1 diabetes[J]. BMJ open, 2018, 8(7): e022353.

[16]Schoor R, Bruce A, Bruce J, et al. Reasons for nonadherence and response to treatment in an adherence intervention trial for relapsing-remitting multiple sclerosis patients[J]. Journal of clinical psychology, 2019, 75(3): 380-391.

[17]Grace Cannard K, Hacker M L, Molinari A, et al. Recruitment and Retention in Clinical Trials of Deep Brain Stimulation in Early-Stage Parkinson's Disease: Past Experiences and Future Considerations[J]. Journal of Parkinson's disease, 2018, 8(3): 421-428.

[18]Grape A, Rhee H, Wicks M, et al. Recruitment and retention strategies for an urban adolescent study: lessons learned from a multi-center study of community-based asthma self-management intervention for adolescents[J]. Journal of adolescence, 2018, 65: 123-132.

[19]Daykin A, Clement C, Gamble C, et al. 'Recruitment, recruitment, recruitment'-the need for more focus on retention: a qualitative study of five trials[J]. Trials, 2018, 19(1): 76.

[20]Arame Thiam-Diouf, Barbara Metch , Cameron Sharpe ,etc.Substance use patterns of HVTN phase I clinical trial participants: Enrollment, risk reduction counseling and retention[J].Vaccine,2018,36(9):1235-1242.

Page $7 / 30$ 
[21]YS Xu, S Wei, YC Zeng, et al. Investigation of factors influencing the compliance of subjects in drug clinical trials and nursing strategies [J]. Journal of Clinic Nursing's Practicality, 2018, 3 (33): 29- 30. DOI: 10.3969 / j.issn.2096-2479.2018.33.024.

[22]Joshua Wynne,Rosemary Muwawu,Michael C Mubiru,Betty Kamira,Doreen Kemigisha,Teopista Nakyanzi,Samuel Kabwigu,Clemensia Nakabiito,Flavia Kiweewa Matovu. Maximizing participant retention in a phase 2B HIV prevention trial in Kampala, Uganda: The MTN-003 (VOICE) Study[J]. HIV Clinical Trials,2018,19(5).

[23]Minick S G , May S B , Rivet A K , et al. Participants' perspectives on improving retention in HIV care after hospitalization: A post-study qualitative investigation of the MAPPS study[J]. PLOS ONE, 2018, 13(8):e0202917.

[24]Chhatre S , Jefferson A , Cook R , et al. Patient-centered recruitment and retention for a randomized controlled study[J]. Trials, 2018, $19(1): 205$.

[25]Carter Rosalind J, Senesi Reynold G B, Dawson Peter,ETC. Participant Retention in a Randomized Clinical Trial in an Outbreak Setting: Lessons From the Sierra Leone Trial to Introduce a Vaccine Against Ebola (STRIVE)[J]. Journal of Infectious Diseases, 2018(suppl_1):suppl_1.

[26]Y Xiong. Experience of subject compliance management in phase I drug clinical trials [J] .Diet Health, 2018,5 (20): 46 . DOI: c 10.3969 / j.issn.20958439.2018.20.055.

[27] Okhomina V I, Seals S R, Anugu P, et al. Adherence and retention of African Americans in a randomized controlled trial with a yoga-based intervention: the effects of health promoting programs on cardiovascular disease risk study[J]. Ethnicity \& Health, 2018: 1-13.

[28]Rios-Romenets S, Acosta-Baena N, Lopez L, et al. Adherence/Retention Alzheimer's Prevention Initiative Colombia Plan[J]. Alzheimer's \& Dementia: Translational Research \& Clinical Interventions, 2018, 4: 283-287.

[29]Ulrich C M, Deshmukh S, Pugh S L, et al. Attrition in NRG Oncology's Radiation-Based Clinical Trials[J]. International Journal of Radiation Oncology* Biology* Physics, 2018, 102(1): 26-33.

[30]JX Tao, XD Li , HL Liang, TQ He, M Ren , CX Lu , MQ Yu , DY Yan, YL Huangfu. Bushen Quxie Fang combined with entecavir in the treatment of chronic hepatitis B in a multi-center clinical study of subjects'clinical compliance and influencing factors[J].Journal of Traditional Chinese Medicine,2018,59(19):16611666.DOI:10.13288/j.11-2166/r.2018.19.011.

[31]JH Liu. Study on the effect of nursing intervention on subject compliance in drug clinical trials [J]. Special Health, 2018 (16).

[32]J Yang, XQ Liu, L Fan, et al. Analysis and counterpotential approaches of subject management in the phase I clinical trials of drugs [J]. Medical Diet and Health, 2018, (5): 187,190.

[33]Joanna C Crocker,Ignacio Ricci-Cabello,Adwoa Parker,Jennifer A Hirst,Alan Chant,Sophie Petit-Zeman,David Evans,Sian Rees. Impact of patient and public involvement on enrolment and retention in clinical trials: systematic review and meta-analysis[J]. BMJ,2018,363.

[34]Boada M, Santos-Santos M A, Rodríguez-Gómez O, et al. Patient engagement: the fundacío ACE framework for improving recruitment and retention in Alzheimer's disease research[J]. Journal of Alzheimer's Disease, 2018, 62(3): 1079-1090.

[35] HL Duan , ZJ Du , WR Zhang , XF Dong. Based on literature review of influencing factors of subject compliance[J]. World Latest Medicine Information,2018,18(98):146-148.DOI:10.19613/j.cnki.1671-3141.2018.98.063.

[36]Babatunde O A, Adams S A, Wirth M D, et al. Predictors of retention among African Americans in a randomized controlled trial to test the Healthy Eating and Active Living in the Spirit (HEALS) intervention[J]. Ethnicity \& disease, 2017, 27(3): 265.

[37]Julia Lawton , David White, David Rankin ,etc.Staff experiences of closing out a clinical trial involving withdrawal of treatment: qualitative study[J].Trials,2017,18:61.

[38]J. Lloyd, C. McHugh, J. Minton,etc. The impact of active stakeholder involvement on recruitment, retention and engagement of schools, children and their families in the cluster randomised controlled trial of the Healthy Lifestyles Programme (HeLP): a school-based intervention to prevent obesity[J].Trials,2017,18(1):378.

[39]David A. Rorie, Robert W. V. Flynn , Isla S. Mackenzie,etc. The Treatment In Morning versus Evening (TIME) study: analysis of recruitment, follow-up and retention rates post- recruitment[J].Trials,2017,18(1):557.

[40]HM Wang,HJ Li. Analysis of full-course nursing intervention to improve the compliance of malignant tumor subjects in drug clinical trials [J]. Journal of Clinic Nursing's Practicality, 2017, 2 (44): 133,138. DOI: 10.3969 / j. issn.2096-2479.2017.44.111.

[41]Pfammatter Angela Fidler,Mitsos Alexa,Wang Shirlene,Hood Susan Hammett,Spring Bonnie. Evaluating and improving recruitment and retention in an mHealth clinical trial: an example of iterating methods during a trial.[J]. mHealth,2017,3.

[42]Kannisto Kati Anneli,Korhonen Joonas,Adams Clive E,Koivunen Marita Hannele,Vahlberg Tero,Välimäki Maritta Anneli. Factors Associated With Dropout During Recruitment and Follow-Up Periods of a mHealth-Based Randomized Controlled Trial for Mobile.Net to Encourage Treatment Adherence for People With Serious Mental Health Problems.[J]. Journal of medical Internet research,2017,19(2). 
[43]Kearney Anna,Daykin Anne,Shaw Alison R G,Lane Athene J,Blazeby Jane M,Clarke Mike,Williamson Paula,Gamble Carrol. Identifying research priorities for effective retention strategies in clinical trials.[J]. Trials,2017,18(1).

[44]Paul A. Leighton,Stephen D. Brealey,Joseph J. Dias. Interventions to improve retention in a surgical, clinical trial: A pragmatic, stakeholder-driven approach[J]. Journal of Evidence-Based Medicine,2018,11(1).

[45]Lawrie T A, Betrán A P, Singata-Madliki M, et al. Participant recruitment and retention in longitudinal preconception randomized trials: lessons learnt from the Calcium And Pre-eclampsia (CAP) trial[J]. Trials, 2017, 18(1): 500.

[46] Beishuizen C R L, Coley N, Moll van Charante E P, et al. Determinants of dropout and nonadherence in a dementia prevention randomized controlled trial: The prevention of dementia by intensive vascular care trial[J]. Journal of the American Geriatrics Society, 2017, 65(7): 1505-1513.

[47]Comerford M, Lourens S, Liangpunsakul S, et al. Challenges in patient enrollment and retention in clinical studies for alcoholic hepatitis: Experience of the TREAT Consortium[J]. Alcoholism: Clinical and Experimental Research, 2017, 41(12): 2000-2006.

[48]Ware, R.S., L. McPherson and N.G. Lennox, Drop-out during a randomized trial with adolescents with intellectual disability was associated with participant burden, while drop-out at study exit was associated with carer and household characteristics. Research in Developmental Disabilities, 2017. 71: 53-60.

[49]ZC Cai . Factors influencing the compliance of subjects in clinical trials of antitumor drugs and pharmaceutical interventions[J].Chinese Community Doctors,2017,33(09):13+15.DOI:10.3969/j.issn.1007-614x.2017.9.6.

[50]JJ Jin , GM Zhang , SS Song, et al. Discussion on the management of subjects in the clinical trial of phase $\otimes$ drugs for blood diseases [J]. Journal of Nurses Training, 2017, 32 (15): 1378-1380. DOI: 10.16821 / j.cnki .hsjx.2017.15.011.

[51]YW Zhang, Y Li. Analysis of the causes of subject dropout and clinical counterpotential approaches in clinical trials of drugs . For All Health, 2017,11(7):13.

[52]Y Jin,QY Zhang,LR Li.Analysis and counterpotential approaches of the drop-out of subjects in clinical trials of breast cancer drugs[J].Chinese Clinical Oncology,2017,22(2):161-166. DOI:10.3969/j.issn.1009-0460.2017.02.013.

[53] Kadam R A, Borde S U, Madas S A, et al. Challenges in recruitment and retention of clinical trial subjects[J]. Perspectives in clinical research, 2016, 7(3): 137.

[54]Ashley Salazar, Susan Tolivaisa, Donna Allard,etc. What We Have Learned About Best Practices for Recruitment and Retention in Multicenter Pregnancy Studies[J].Semin Perinatol,2016,40(5):321-327.

[55]CJ Feng, L Yue,YR Jiang.Discussion on the causes and counterpotential approaches of subject dropout in clinical trials of endocrine professional drugs [J] .Medical Frontier, $2016,6(9):$ 233-234.

[56]Thayabaranathan T, Cadilhac DA, Srikanth VK,etc.Maximizing Patient Recruitment and Retention in a Secondary Stroke Prevention Clinical Trial: Lessons Learned from the STAND FIRM Study[J].J Stroke Cerebrovasc Dis,2016,25(6):1371-1380.

[57]Atherton P J , Burger K N , Pederson L D , et al. Patient-reported outcomes questionnaire compliance in Cancer Cooperative Group Trials (Alliance N0992) [J]. Clinical Trials, 2016:1740774516655101.

[58]HB Zhang. Nursing management of subject follow-up compliance in phase III drug clinical trials [J]. Nursing and Rehabilitation Journal, 2016, 15 (4): $375-$ 377. DOI: 10.3969 / j.issn.1671- 9875.2016 .04 .022$.

[59]Miguel, A. Q. C., Madruga, C. S., Cogo-Moreira, H., Yamauchi, R., Simões, V., da Silva, C. J., McPherson, S., Roll, J. M., \& Laranjeira, R. R. Contingency management is effective in promoting abstinence and retention in treatment among crack cocaine users in Brazil: A randomized controlled trial. Psychology of Addictive Behaviors, 2016, 30(5): 536-543. https://doi.org/10.1037/adb0000192

[60]Comeli A. Reasons for subjects' unwillingness to comply in clinical trials of pre-exposure preventive medicine [J]. Chinese Journal of Preventive Medicine, 2016, 50 (9): 793-793.

[61]HY Fan ,XJ Wang , S Jing, et al. Analysis of the causes of shedding of subjects in clinical trials of antihypertensive drugs and strategies[J].Chinese Journal of Medical Science Research Management,2016,29(3):173-175,184. DOI:10.3760/cma.j.issn.1006-1924.2016.03.004.

[62]HY Li , FF Feng, ZW Tian, LL Wang . Factors influencing the compliance of subjects in clinical trials of antitumor drugs and pharmaceutical intervention[J].World Latest Medicine Information,2016,16(04):173-174.

[63]H Zhang, J He, X Zhao, et al. Nursing intervention of the study nurse's compliance with the subjects in the phase I clinical trial of drugs [J]. Military Medical Journal of Southeast China, 2016, 18 (1): 86-87, 108. DOI: 10.3969 / j.issn.1672-271X.2016.01.028.

[64]GX Chen. On the management of subject compliance in clinical trials of new drugs [J]. Journal of Medicine \& Pharmacy of Chinese Minorities, 2016,22 (3): 55-56. DOI: 10.3969 / j.issn.1006-6810.2016. 03.035.

Page $9 / 30$ 
[65]Louise Robinson,Pauline Adair,Margaret Coffey,Rebecca Harris,Girvan Burnside. Identifying the participant characteristics that predict recruitment and retention of participants to randomised controlled trials involving children: a systematic review[J]. BioMed Central,2016,17(1).

[66]Berge E , Stapf C , Al-Shahi Salman R ,etc.Methods to improve patient recruitment and retention in stroke trials[J].International Journal of Stroke,2016,11(6):663-676.

[67]Shiovitz T M , Bain E E , Mccann D J , et al. Mitigating the Effects of Nonadherence in Clinical Trials[J]. Journal of Clinical Pharmacology, 2015, 56(9):1151-1164.

[68]Moodie E E M, Karran J C, Shortreed S M. A case study of SMART attributes: a qualitative assessment of generalizability, retention rate, and trial quality[J]. Trials, 2016, 17(1): 242.

[69]V C Brueton, J F Tierney, S Stenning,etc.Strategies to improve retention in randomised trials: a Cochrane systematic review and meta-analysis[J].BMJ Open,2014,2(4):e003821.

[70]Johnson Natalie A,Kypri Kypros,Latter Joanna,McElduff Patrick,Attia John,Saitz Richard,Saunders John B,Wolfenden Luke,Dunlop Adrian,Doran Christopher,McCambridge Jim. Effect of telephone follow-up on retention and balance in an alcohol intervention trial.[J]. Preventive medicine reports,2015,2.

[71]Boden-Albala, Bernadette,Carman, Heather,Southwick, Lauren, et al.Examining Barriers and Practices to Recruitment and Retention in Stroke Clinical Trials[J].Stroke: A Journal of Cerebral Circulation,2015,46(8):2232-2237.

[72]Blaha Robert Z,Arnett Anne B,Kirkwood Michael W,Taylor H Gerry,Stancin Terry,Brown Tanya M,Wade Shari L. Factors influencing attrition in a multisite, randomized, clinical trial following traumatic brain injury in adolescence.[J]. The Journal of head trauma rehabilitation,2015,30(3).

[73]Barbro L , Kristian L , Judith B , et al. Participant Experiences in the Environmental Determinants of Diabetes in the Young Study: Common Reasons for Withdrawing[J]. Journal of Diabetes Research, 2016, 2016:1-13.

[74]ComeliA, Perry B, McKenna K, et al. Participants' explanations for non-adherence in the FEM-PrEP clinical trial[J]. E PIDEMIOLOGY AND P REVENTION, 2015.

[75]Langford D P, Fleig L, Brown K C, et al. Back to the future-feasibility of recruitment and retention to patient education and telephone follow-up after hip fracture: a pilot randomized controlled trial[J]. Patient preference and adherence, 2015, 9: 1343.

[76]Olds, D.L., Baca, P., McClatchey, M. et al. Cluster Randomized Controlled Trial of Intervention to Increase Participant Retention and Completed Home Visits in the Nurse-Family Partnership. Prev Sci, 2015, 16:778-788. https://doi.org/10.1007/s11121-015-0563-x.

[77]XX Wang. Analysis of the effect of compliance education on clinical trial subjects[C]. Chinese Journal of Hypertension.Chinese Journal of Hypertension:Chinese Journal of Hypertension,2015:534.

[78]L Zhang, JM Guo, CQ Kang, et al. Analysis and counterpotential approaches of the subject management of drug clinical trials in our hospital [J]. China Medical Herald, 2015, 12 (6): 140-144.

[79]M Yang. Analysis of the reasons for the drop-out of subjects in the Phase I clinical trial of drugs and counterpotential approaches [J]. Medicine and Health Care, 2015, (10): 209-210.

[80]Tangrea, J. A . Patient Participation and Compliance in Cancer Chemoprevention Trials: Issues and Concerns[J]. Experimental Biology \& Medicine, 1997, 216(2):260-265.

[81]Mood L, Hassouneh D, McNeff E. A Conceptual Model to Promote the Retention of Women with Physical Disabilities in Research[J]. Public Health Nursing, 2015, 32(4): 368-377.

[82]Wells A A, Palinkas L A, Williams S L L, et al. Retaining low-income minority cancer patients in a depression treatment intervention trial: Lessons learned[J]. Community mental health journal, 2015, 51(6): 715-722.

[83]Carlson M, Jackson J, Mandel D, et al. Predictors of retention among African American and Hispanic older adult research participants in the well elderly 2 randomized controlled trial[J]. Journal of Applied Gerontology, 2014, 33(3): 357-382.

[84]Marjorie C. McCullagh, Marie-Anne Sanon, Michael A. Cohen.Strategies to enhance participant recruitment and retention in research involving a community-based population[J].Applied Nursing Research,2014,27(4).

[85]Mary Fischer, WHNP-BC, NCMP,etc.Use of pragmatic community-based interventions to enhance recruitment and adherence in a randomized trial of Tai Chi for women with osteopenia: insights from a qualitative substudy[J].Menopause,2014,21(11):1181-1189.

[86]W Wang. The effect of psychological intervention on the compliance of the new drug phase III clinical trial subjects [J]. Today Nurse (Late Journal), 2014, (12): 109-110. 
[87]XW Qiao.Investigation and Analysis of the Causes of the Shedding of the Subjects with Inhalation of Phlegm Heat Clearing Atomization [J].Nei Mongol Journal of Traditional Chinese Medicine,2014,33(21):88-89. DOI:10.3969/j.issn.1006-0979.2014.21.096.

[88]Busisiwe Magazi,Jonathan Stadler,Sinead Delany-Moretlwe,Elizabeth Montgomery,Florence Mathebula,Miriam Hartmann,Ariane van der Straten. Influences on visit retention in clinical trials: Insights from qualitative research during the VOICE trial in Johannesburg, South Africa[J]. BioMed Central,2014,14(1).

[89]Olubukola T Idoko,Olumuyiwa A Owolabi,Aderonke A Odutola,Olatunde Ogundare,Archibald Worwui,Yauba Saidu,Alison Smith-Sanneh,Abdoulie Tunkara,Gibbi Sey,Assan Sanyang,Philip Mendy,MartinO C Ota. Lessons in participant retention in the course of a randomized controlled clinical trial[J]. BioMed Central,2014,7(1).

[90]Kim R , Hickman N , Gali K, et al. Maximizing Retention With High Risk Participants in a Clinical Trial[J]. American Journal of Health Promotion, 2014, 28(4):268-274.

[91]LP Mai, YH Wu, XP Wang, et al. Discussion on the methods of subject management in Phase I clinical trials of drug [J]. The Journal of Evidence-Based Medicine, 2014, 14 (4): 240-243, 256. DOI: 10.3969 / j. issn.1671-5144.2014.04.015.

[92]Q Zhang. How to improve the compliance of subjects in clinical trials of drugs [J]. Medical Information, 2014, (37): 389-389. DOI: 10.3969/j.issn.10061959.2014.37.603.

[93]YG Li, Q Yang, JE Zeng, et al. Causes and counterpotential approaches of subject dropout in clinical trials of drugs [J]. Herald of Medicine, 2014, (7): 975976. DOI: 10.3870 / yydb. 2014.07.042

[94]P Huang,R Zuo ,CH Xia ,YQ Xiong . On the experience of subject management in Phase I clinical trials [J]. Chinese Journal of Clinical Pharmacology and Therapeutics, 2014, 19 (03): 320-322.

[95]YG Li, JE Zeng,Q Yang, et al. Talking about informed consent of drug clinical trials and subject compliance [J]. Medical Information, 2014, (3): 46-46. DOI: 10.3969 / j.issn .1006-1959.2014.03.057.

[96]J Wei,HL Liu,LC Wang.Discussion on strategies to improve the compliance of subjects in clinical trials of acupuncture and moxibustion [J].Beijing Journal of Traditional Chinese Medicine,2014,33(2):97-99.

[97]WK Zheng, B Chang, J Chen. Improving participant adherence in clinical research of traditional chinese medicine.[J]. Evidence-based complementary and alternative medicine : eCAM,2014:376058.

[98]Lopes R T, Gonçalves M M, Sinai D, et al. Predictors of dropout in a controlled clinical trial of psychotherapy for moderate depression[J]. International Journal of Clinical and Health Psychology, 2015, 15(1): 76-80.

[99]Knippschild S, Hirsch J, Krummenauer F. Metaanalysis to estimate the expected drop out-rates reported in clinical trials on cataract surgery[J]. 2014.

[100]Plummer M L, Watson-Jones D, Lees S, et al. A qualitative study of participant adherence in a randomized controlled trial of herpes suppressive therapy for HIV prevention in Tanzania[J]. AIDS care, 2010, 22(4): 499-508.

[101]Warner E T, Glasgow R E, Emmons K M, et al. Recruitment and retention of participants in a pragmatic randomized intervention trial at three community health clinics: results and lessons learned[J]. BMC public health, 2013, 13(1): 192.

[102]Murphy E J, Kassem L, Chemerinski A, et al. Retention and attrition among African Americans in the STAR* D study: what causes research volunteers to stay or stray?[J]. Depression and anxiety, 2013,30(11): 1137-1144.

[103]Margaret Pribulick, Ishan Canty Willams, Pamela Stewart Fahs,etc.STRATEGIES TO REDUCE BARRIERS TO RECRUITMENT AND PARTICIPATION[J].Online J Rural Nurs Health Care,2013,10(1):22-33.

[104]V C Brueton, F Stevenson, C L Vale,etc. Use of strategies to improve retention in primary care randomised trials: a qualitative study with in-depth interviews[J].BMJ Open,2014,4:e003835.

[105] CC Xia, YJ Zhu. Influencing factors and pharmaceutical interventions of subjects 'compliance in clinical trials of stroke treatment drugs [J]. China Modern Medicine, 2013, 20 (31): 154-155.

[106]Lewis AL, Baker N, Carpenter M,etc.Does physician continuity within a clinical trial increase retention and compliance among adolescent smokers?[J]. Adolesc Psychiatry (Hilversum),2013,3(2).

[107]SY Liu , ZF Jiang , XY Yu . Nursing intervention of subject compliance in clinical trials of HER-2 positive early breast cancer drugs[J].Chinese Journal of Modern Nursing,2013,19(27):3323-3325. DOI:10.3760/cma.j.issn.1674-2907.2013.27.007.

[108]SZ Hu. Compliance analysis and intervention potential approaches in clinical trials of asthma patients [J]. Health Required (Late Journal), 2013, (8): 459460 . 
[109]Atassi N, Yerramilli-Rao P, Szymonifka J, et al. Analysis of start-up, retention, and adherence in ALS clinical trials[J]. Neurology, 2013, 81(15): 1350-1355. [110]Koog Y H, Gil M, We S R, et al. Barriers to participant retention in knee osteoarthritis clinical trials: a systematic review[C]//Seminars in arthritis and rheumatism. WB Saunders, 2013, 42(4): 346-354.

[111]Gatehouse C S, Tennen H A, Feinn R S, et al. Association between interactive voice response adherence and subject retention in a randomized controlled trial[J]. Contemporary clinical trials, 2012, 33(4): 589-592.

[112]YY Kou , YQ Tang , JQ Wu , Y Zhang , M Li , JF Feng . Factors influencing the compliance of subjects in clinical trials of antitumor drugs and pharmaceutical interventions[J].China Pharmacy,2012,23(18):1711-1713.DOI:10.6039/j.issn.1001-0408.2012.18.32.

[113]QW Rao. Management of subjects 'compliance with medication in clinical trials of drugs [J]. Chinese Journal of Aesthetic Medicine, 2012, 21 (14): 693694. DOI: 10.3969 / j.issn. 14.534.

[114] YM Hu, JY Zhao, JH Jiang, et al. Analysis of the reasons for the shedding of subjects in clinical trials of a hospital and discussion on the counterpotential approaches [J]. Anhui Medical Journal, 2012, 33 (2): 214-216. DOI: 10.3969 / j. issn.1000-0399.2012.02.038.

[115]Vellas B , Hampel H, Rouge-Bugat M E , et al. Alzheimer's disease therapeutic trials: EU/US task force report on recruitment, retention, and methodology[J]. journal of nutrition health \& aging, 2012, 16(4):339-345.

[116] Hui D, Glitza I, Chisholm G, et al. Attrition rates, reasons, and predictive factors in supportive care and palliative oncology clinical trials[J]. Cancer, 2013, 119(5): 1098-1105.

[117]Y Zhang ,L Shi , WJ Jiang , XH Zeng . Influencing factors and counterpotential approaches of compliance in clinical trials[J].China Pharmaceuticals,2012,21(02):13-14. DOI:10.3969/j.issn.1006-4931.2012.02.008.

[118]Collins B N, Wileyto E P, Hovell M F, et al. Proactive recruitment predicts participant retention to end of treatment in a secondhand smoke reduction trial with low-income maternal smokers[J]. Translational behavioral medicine, 2011, 1(3): 394-399.

[119]Deborah A. Gust,Barudi Mosimaneotsile,Unami Mathebula, et al.Risk Factors for Non-Adherence and Loss to Follow-Up in a Three-Year Clinical Trial in Botswana[J].,2011.

[120]Sue Penckofer,Mary Byrn,Patricia Mumby,Carol Estwing Ferrans. Improving Subject Recruitment, Retention, and Participation in Research through Peplau's Theory of Interpersonal Relations[J]. Nursing Science Quarterly,2011,24(2).

[121]Brubaker L , Richter H E , Barber M D , et al. Pelvic floor disorders clinical trials: participant recruitment and retention[J]. International Urogynecology Journal, 2013, 24(1):73-79.

[122]BURGESS, L, J, et al. Patient retention gifts in clinical trials: undue inducement or justified motivational tools?.[J]. Samj South African Medical Journal, 2011.

[123]Kalkhuis-Beam S, Stevens SL, Baumritter A,etc.Participant- and study-related characteristics predicting treatment completion and study retention in an adolescent smoking cessation trial.[J].Journal of Adolescent Health,2011,49(4):371-378.

[124]XN Wang ,YQ Yuan, SH Fan, et al. Effect of nursing intervention on subject compliance in drug clinical trials[J].CHINESE JOURNAL OF MODERN NURSING,2011,17(19):2285-2287. DOI:10.3760/cma.j.issn.1674-2907.2011.19.019.

[125]J Xiong, ZH Chi,RX Chen.Discussion on improving the compliance of multi-center moxibustion clinical trial subjects [J].China Journal of Traditional Chinese Medicine and Pharmacy,26(8):1780-1782.

[126]Burgess L M, Sulzer N U. Retrospective analysis of a South African cardiovascular trial site' s patient retention rates[J]. Open Access J Clin Trials, 2010, 2: 163-166.

[127]Anne-Marie Shields, Mihyun Park, Sandra E. Ward,etc.Subject Recruitment and Retention Against Quadruple Challenges in an Intervention Trial of End-ofLife Communication[J].J Hosp Palliat Nurs,2010,12(5):312-318.

[128]CM Zhai, LN Xia, DY Huang, et al. Observation of the effect of holistic nursing on subject compliance in clinical trials of new drugs [J]. China Foreign Medical Treatments, 2010, 29 (25): 161. DOI: 10.3969 / j.issn. 1674-0742.2010.25.129.

[129]Grill J D, Karlawish J. Addressing the challenges to successful recruitment and retention in Alzheimer's disease clinical trials[J]. Alzheimer's research \& therapy, 2010, 2(6): 34 .

[130]Magner R,Borg A,Rosal MC, et al.Translational research at community health centers: challenges and successes in recruiting and retaining low-income Latino patients with type 2 diabetes into a randomized clinical trial.[J].The Diabetes educator,2010,36(5):733-749.

[131]Gul B R, Ali A P, et al, Clinical trials: the challenge of recruitment and retention of participants. Journal of Clinical Nursing, $2010,19: 227-233$.

doi:10.1111/j.1365-2702.2009.03041.x

Page $12 / 30$ 
[132]Lindström D, et al., Disappointment and drop-out rate after being allocated to control group in a smoking cessation trial. Contemporary Clinical Trials, 2010. 31(1): 22-26.

[133]YJ Huang , SB Ding. Influencing factors and potential approaches of subject compliance in anti-tumor drug clinical trials[J].INTERNATIONAL JOURNAL OF NURSING,2010,29(2):308-309. DOI:10.3760/cma.j.issn.1673-4351.2010.02.072.

[134]DC Fan. Methods of evaluating and improving subject compliance [J]. China Prescription Drug, 2010, (4): 70-71.

[135]DC Fan.Analysis method of enrollment rate and subject's compliance [J].China Prescription Drug,2010,(3):70-71.

[136]GD Lu, SH Xi, R Li, et al. Analysis and counterpotential approaches of subjects 'individual non-compliance factors in drug clinical trials [J]. Nursing Journal of Chinese People's Liberation Army, 2009, 26 (9): 30-31, 50. DOI: 10.3969 / j.issn.1008-9993.2009.09.010.

[137]Haleh Sangi-Haghpeykar, Hannah M. Meddaugh, H Liu,etc.Attrition and retention in clinical trials by ethnic origin[J].Contemporary Clinical Trials,2009,30:499-503.

[138]Merran Toerien, Sara T Brookes, Chris Metcalfe,etc.A review of reporting of participant recruitment and retention in RCTs in six major journals[J].Trials,2009,10:52.

[139]HY Liu, JX Chen, L Xia, et al. Influencing factors and counterpotential approaches of subject compliance in clinical trials of traditional Chinese medicine new drugs [J]. Zhejiang Journal of Traditional Chinese Medicine, 2009, 44 (12): 923. DOI: 10.3969 / j. issn.0411-8421.2009.12.044.

[140]LJ Tian,SX Wang,XJ Gao.Psychological investigation and intervention potential approaches of subjects before participating in clinical trials [J].Hebei Medical Journal,2009,31(13):1674-1675. DOI:10.3969/j.issn.1002-7386.2009.13.082.

[141]SX Wang, SJ Zhang.Analysis of the reasons why the subjects completed the clinical trial [J].

Nursing Practice and Research,2009,6(19):124-125. DOI:10.3969/j.issn.1672-9676.2009.19.072.

[142]Guzmn Anglica,Richardson Irma M,Gesell Sabina,Barkin Shari L. Recruitment and Retention of Latino Children in a Lifestyle Intervention[J]. American journal of health behavior,2009,33(5).

[143]Claire S Leathem,Margaret E Cupples,Mary C Byrne,Mary O'Malley,Ailish Houlihan,Andrew W Murphy,Susan M Smith. Identifying strategies to maximise recruitment and retention of practices and patients in a multicentre randomised controlled trial of an intervention to optimise secondary prevention for coronary heart disease in primary care[J]. BioMed Central,2009,9(1).

[144] Chang MW, Brown R, Nitzke S.Participant recruitment and retention in a pilot program to prevent weight gain in low-income overweight and obese mothers[J].BMC Public Health,2009,9:24. https://doi.org/10.1186/1471-2458-9-424

[145]Cox LE.Predictors of medication adherence in an AIDS clinical trial: patient and clinician perceptions[J].Health Soc Work,2009,34(4):257264.https://doi.org/10.1093/hsw/34.4.257.

[146]X Zhang, Y Zhang, YH Zhao. Reflections on compliance issues in clinical trials of new drugs [J]. MEDICINE AND PHILOSOPHY, 2009, 30 (24): 69-70.

[147]XX Wang,YM Li,J Gao.Study on the subject's compliance in clinical trials of drugs [J].Chinese Remedies \& Clinics,2009,9(6):507-508.

DOI:10.3969/j.issn.1671-2560.2009.06.019.

[148]YP Bao , Z Liu, Epstein D H, et al. A meta-analysis of retention in methadone maintenance by dose and dosing strategy[J]. The American journal of drug and alcohol abuse, 2009, 35(1): 28-33.

[149]SM Xue . Causes and management of shedding cases in clinical trials of new orthopedic drugs[J].Chinese Journal of Current Hospital Adminestration,2009,007(012).

[150]Sharika Gappoo, Elizabeth T. Montgomery, Caitlin Gerdts, et al. Novel strategies implemented to ensure high participant retention rates in a community based HIV prevention effectiveness trial in South Africa and Zimbabwe[J]. Contemporary Clinical Trials, 2009, 30(5):411-418.

[151]Higginson Irene, Hart Sam,Burman Rachel,Silber Eli,Saleem Tariq,Edmonds Polly. Randomised controlled trial of a new palliative care service:

Compliance, recruitment and completeness of follow-up[J]. BMC Palliative Care,2008,7(1).

[152]Siddiqi A A, Sikorskii A, Given C W, et al. Early participant attrition from clinical trials: role of trial design and logistics[J]. Clinical Trials, 2008, 5(4): 328335.

[153]GD Lu ,LL Zhang, QY Xiu , et al. Analysis and treatment of the subject 's shedding in clinical trials of drugs [J]. Nursing Journal of Chinese People's Liberation Armyl, 2008, 25 (20): 17-19. DOI: 10.3969 /j.issn.1008-9993.2008.20.007.

[154]GD Lu ,LL Zhang. Subject compliance management in clinical trials of drugs [J]. Hospital Administration Journal of Chinese People's Liberation Army, 2008, 15 (3): 293-295. DOI: 10.3969 / j.issn. 9985.2008.03.048. 
[155]S. S. Bull,D. Vallejos,D. Levine,C. Ortiz. Improving recruitment and retention for an online randomized controlled trial: experience from the Youthnet study[J]. AIDS Care,2008,20(8).

[156]Victoria Villacorta, Susan Kegeles, Jerome Galea,etc.Innovative approaches to cohort retention in a community-based HIV/STI prevention trial for socially marginalized Peruvian young adults[J].Clinical Trials,2007,4:32-41.

[157]Glasgow Russell E,Nelson Candace C,Kearney Kathleen A,Reid Robert,Ritzwoller Debra P,Strecher Victor J,Couper Mick P,Green Beverly,Wildenhaus Kevin. Reach, engagement, and retention in an Internet-based weight loss program in a multi-site randomized controlled trial.[J]. Journal of medical Internet research,2007,9(2).

[158]J Xiao, F Tan, B Chen. Subject compliance issues in clinical trials of new drugs [J]. Chinese Journal of New Drugs, 2007,16 (6): $420-423$. DOI: 10.3321 / j.issn: 1003-3734.2007.06.002.

[159]Maurice Andrew,Howell Anthony,Evans D Gareth,O'Neil Alison C,Scobie Sue. Predicting compliance in a breast cancer prevention trial.[J]. The breast journal,2006,12(5).

[160]Mor M, Niv G, Niv Y.Patient Retention in a Clinical Trial: A Lesson from the Rofecoxib (VIOXX) Study[J].Digestive Diseases and Sciences,2006,51(7):11751178.

[161]Dias L, Schoenfeld E, Thomas J, et al. Reasons for high retention in pediatric clinical trials: comparison of participant and staff responses in the Correction of Myopia Evaluation Trial[J]. Clinical Trials, 2005, 2(5): 443-452.

[162]Wiemann C M , Chacko M R , Tucker J C , et al. Enhancing Recruitment and Retention of Minority Young Women in Community-Based Clinical Research[J]. J Pediatr Adolesc Gynecol, 2005, 18(6):403-407.

[163]Avins A L, Bent S, Neuhaus J M. Use of an embedded N-of-1 trial to improve adherence and increase information from a clinical study[J]. Contemporary clinical trials, 2005, 26(3): 397-401.

[164]Steven K, Dobscha, Kathryn Corson, Jeffrey Solodky, and Martha S. Gerrity. Use of Vission Research:Enrollment, Retention, and Patient Satisfaction.Telemedicine and e-Health.2005, 11: 84-89.http://doi.org/10.1089/tmj.2005.11.84

[165]J Zhang, GX Lin, XW Zhang. Talking about the compliance of subjects and researchers in clinical trials of new drugs [J].Liaoning Journal of Traditional Chinese Medicine, 2005, 32 (8): 854-855. DOI: 10.3969 / j. issn.1000-1719.2005.08.083.

[166]Raymond E G, Chen P L, Pierre-Louis B, et al. Participant characteristics associated with withdrawal from a large randomized trial of spermicide effectiveness[J]. BMC medical research methodology, 2004, 4(1): 23.

[167]Mazzuca S A, Brandt K D , Katz B P, et al. Subject retention and adherence in a randomized placebo-controlled trial of a disease-modifying osteoarthritis drug[J]. Arthritis \& Rheumatism, 2004, 51(6):933-940.

[168]de Bruyn, et al, Participant Retention in Clinical Trials of Candidate HIV Vaccines. JAIDS Journal of Acquired Immune Deficiency Syndromes, 2005. 39(4).

[169]Sears S R, Stanton A L, Kwan L, et al. Recruitment and retention challenges in breast cancer survivorship research: results from a multisite, randomized intervention trial in women with early stage breast cancer[J]. Cancer Epidemiology and Prevention Biomarkers, 2003, 12(10): 1087-1090.

[170]Bender B G, Ellison M C, Gleason M, et al. Minimizing attrition in a long-term clinical trial of pediatric asthma[J]. Annals of Allergy, Asthma \& Immunology, 2003, 91(2): 168-176.

[171]Adubato S, Alper R, Heenehan M, et al. Successful ways to increase retention in a longitudinal study of lead-exposed children[J]. Health \& social work, 2003, 28(4): 312-315.

[172]J Zeng ,GM Chen , RL Li . Subject compliance issues in clinical trials of new drugs[J].Chinese Journal of New Drugs and Clinical Remedies,2003(09):568570. DOI:10.3969/j.issn.1007-7669.2003.09.016.

[173]Sonawalla Shamsah B,Farabaugh Amy H,Leslie Vinita M,Pava Joel A,Matthews John D,Fava Maurizio. Early drop-outs, late drop-outs and completers: differences in the continuation phase of a clinical trial[J]. Progress in neuro-psychopharmacology \&amp; biological psychiatry,2002,26(7-8):1415-1419.

[174]Bulpitt Christopher J,Beckett Nigel S,Fletcher Astrid E,Thijs Lutgarde,Staessen Jan A,Dumitrascu Dan L,Forette Francoise,Leonetti Gastone,Nachev Choudomir,Tuomilehto Jaakko,Fagard Robert H. Withdrawal from treatment in the Syst-Eur Trial.[J]. Journal of hypertension,2002,20(2).

[175]David C Mohr, Donald E Goodkin , Lorianne Masuoka,etc. Treatment adherence and patient retention in the first year of a Phase-III clinical trial for the treatment of multiple sclerosis[J].Multiple Sclerosis,1999,5:192-197.

[176]G Jónasson, K H Carlsen, A Sdal, et al. Patient compliance in a clinical trial with inhaled budesonide in children with mild asthma[J]. European Respiratory Journal, 1999, 14(1):150-154. 
[177] Jordhøy M S, Kaasa S, Fayers P, et al. Challenges in palliative care research; recruitment, attrition and compliance: experience from a randomized controlled trial[J]. Palliative medicine, 1999, 13(4): 299-310.

[178]Grilo C M, Money R, Barlow D H, et al. Pretreatment patient factors predicting attrition from a multicenter randomized controlled treatment study for panic disorder[J]. Comprehensive Psychiatry, 1998, 39(6): 323-332.

[179]Bender B G, Iklé D N, DuHamel T, et al. Retention of asthmatic patients in a longitudinal clinical trial[J]. Journal of Allergy and Clinical Immunology, 1997, 99(2): 197-203.

[180]Peter M. Milgrom, Philippe P. Hujoel, Philip Weinstein,etc.Subject Recruitment, Retention, and Compliance in Clinical Trials in Periodontics[J].Annals of Periodontology, 1997,2(1):64-74.

[181]Marion Good,Linda Schuler.Subject retention in a controlled clinical trial[J].Journal of Advanced Nursing,1996,26(2):351-355.

[182]Blumenthal D S, Sung J, Coates R, et al. Mounting research addressing issues of race/ethnicity in health care: recruitment and retention of subjects for a longitudinal cancer prevention study in an inner-city black community[J]. Health Serv Res, 1995, 30: 197-205.

[183]Epstein E E, McCrady B S, Miller K J, et al. Attrition from conjoint alcoholism treatment: Do dropouts differ from completers?[J]. Journal of substance abuse, 1994, 6(3): 249-265.

[184] Boyd N F, Cousins M, Kriukov V. A randomized controlled trial of dietary fat reduction: the retention of subjects and characteristics of drop outs[J]. Journal of clinical epidemiology, 1992, 45(1): 31-38.

[185] Alter M, Lai S M, Tournier B, et al. Acute stroke trials: Reasons for patient withdrawal[J]. Journal of Stroke and Cerebrovascular Diseases, 1991, 1(4): 182189.

[186]Morse EV, Simon PM, Coburn M,etc.Determinants of subject compliance within an experimental anti-HIV drug protocol[J].Social Science \& Medicine,1991,32(10):1161-1167. DOI: 10.1016/0277-9536(91)90093-R

[187]Kvien TK, Reimers S. Drug handling and patient compliance in an outpatient paediatric trial.J Clin Hosp Pharm. 1983 , 8(3):251-7.DOI:10.1111/j.13652710.1983.tb01104.x

[188]Goldman A I, Holcomb R, Perry Jr H M, et al. Can dropout and other noncompliance be minimized in a clinical trial? Report from the Veterans Administrative National Heart, Lung and Blood Institute cooperative study on antihypertensive therapy: mild hypertension[J]. Controlled Clinical Trials, 1982, 3(2): 75-89.

[189]Zoë C Skea, Rumana Newlands, Katie Gillies.Exploring non-retention in clinical trials: a meta-ethnographic synthesis of studies reporting participant reasons for drop out[J].BMJ Open,2019,9(6):e021959.

[190] Geoff K. Frampton*, Jonathan Shepherd, Karen Pickett,etc.Digital tools for the recruitment and retention of participants in randomised controlled trials: a systematic map[J].Trials,2020,21:478.

[191]McKinstry C, Brown T, Gustafsson L. Scoping reviews in occupational therapy: the what, why, and how to[J]. Aust Occup Ther J, 2014, 61(2):58-66ه

[192]Levac D, Colquhoun H, O'Brien KK. Scoping studies: advancing the methodology. Implemen Sci 2010;5:69. https://doi.org/10.1186/1748-5908-5-69.

\section{Tables}

Table.1 The factors that affecting compliance and retention of clinical trials 


\begin{tabular}{|c|c|c|c|c|}
\hline $\begin{array}{l}\text { Influencing } \\
\text { factors }\end{array}$ & Explanation* & Frequency & $\begin{array}{l}\text { Influencing } \\
\text { factors }\end{array}$ & \\
\hline \multicolumn{5}{|c|}{ Individual } \\
\hline Age & $\begin{array}{l}\text { Older people may have poorer compliance and retention due to the bad mobility and memory. But they may also be more } \\
\text { likely to accept researchers' advice than young people. Young people may also have poorer compliance and retention } \\
\text { because they may prefer work or entertainment than participate in clinical trials }{ }^{[11-13,16,21,22,23,25,26,28-33,37,43,45,47,49,50,53,57-} \\
59,61-65,68,70,72,73,75,76,78,80-82,87,88,92,93,98,101,105,106,107,109,112,113,115-117,119,120,123-125,129-132,135,136,139,140,143-147,149-154,156- \\
158,161-163,168-170,172,-174,176-178,182-189]\end{array}$ & $101 / 182$ & Education & \\
\hline Economic & $\begin{array}{l}\text { People with high-income will have higher compliance and retention }{ }^{[9-11,15-18,28,29,31,36,37,40,45,48,49,58,59,61-63,65,71,72,80,81,85,87-} \\
93,97,98,100-103,105,112-114,117-120,123,125,129,130,131,133,139-144,146,147,149,150,152-156,161,162,168,172,178,182,186]\end{array}$ & $76 / 182$ & Gender & \\
\hline $\begin{array}{l}\text { Trust for the } \\
\text { trial }\end{array}$ & $\begin{array}{l}\text { The more trust, the higher compliance and retention }[9,11,12,14,16-19,27,29,31,32,36,38,41,45,47,48,53,55,58,61,63,64,69,71,73,79,81- \\
83,87,92,93,96,97,100,102,103,105,107-109,112,114,116,119,120,124,127,137-139,140,142,146,147,149,152,153,157,161,165,166,172,178,181]\end{array}$ & $66 / 182$ & $\begin{array}{l}\text { Work } \\
\text { commitment }\end{array}$ & I \\
\hline $\begin{array}{l}\text { Special } \\
\text { psychological } \\
\text { characteristics }\end{array}$ & $\begin{array}{l}\text { Special psychological characteristics(anxious, impatience, depression, etc) will reduce the compliance and retention }{ }^{[9,11-} \\
13,15-17,24,30,36-38,41,47,53,64,65,73,75,81,82,90,97,98,100,102,107,110-112,116,118,120,126,132,135,138,140,144,146,151,158,173,175,177-179,181- \\
183,188,189]\end{array}$ & $52 / 182$ & Lost contact & \\
\hline Race & $\begin{array}{l}\text { Patients with different races have different compliance and retention. For example, minorities have lower or higher } \\
\text { compliance and retention }[10,11,13,18,19,25,28,30,31,37,57,71,72,76,81,82,88-90,92,102,109,116,118,120,123,130,136,137,142-144,150,151,153- \\
156,162,168,169,171,185,186]\end{array}$ & $43 / 182$ & Habitat & ( \\
\hline Time & $\begin{array}{l}\text { The more time the patient have, the higher the compliance and retention }{ }^{[10,16,18,19,28,29,30,31,36,43,45,48,56,57,66,69,71-} \\
74,82,88,97,100,103,104,108,110,130,131,135,137,142,144,160,169,170,178,188,189]\end{array}$ & $39 / 182$ & Culture & \\
\hline $\begin{array}{l}\text { Understanding } \\
\text { for the trial }\end{array}$ & $\begin{array}{l}\text { Patients who understand more about the trial may have higher compliance and retention. However, as their understanding } \\
\text { deepens, they may also withdraw because the research does not meet their expectations. } \\
{[11,17,22,31,35,38,41,45,47,48,52,57,61,64,66,71,73,82,87,97,107,119,121,127,138-141,147,153,158,159,165,181]}\end{array}$ & $32 / 182$ & $\begin{array}{l}\text { Expectations } \\
\text { for the trial }\end{array}$ & \\
\hline Character & $\begin{array}{l}\text { The better the character, the higher the compliance and retention } \\
65,70,72,77,79,93,61,63- \\
\end{array}$ & $27 / 182$ & $\begin{array}{l}\text { Interest in the } \\
\text { trial }\end{array}$ & $\mathrm{r}$ \\
\hline Marriage & $\begin{array}{l}\text { Married people may have higher compliance and } \\
\text { retention }[11,23,25,29,30,31,49,76,88,98,107,109,116,130,132,136,151,153,158,161,169,182,183]\end{array}$ & $23 / 182$ & $\begin{array}{l}\text { Life } \\
\text { experience }\end{array}$ & Thents \\
\hline Language & $\begin{array}{l}\text { The degree of matching between researcher's language and patient's language influences compliance and } \\
\text { retention }[9,11,12,49,56,71,73,81,83,100,101,116,130,136,142,162,171]\end{array}$ & $17 / 182$ & Self-efficacy & 7 \\
\hline Dedication & People with dedication will be more compliant ${ }^{[18,48,74,79,80,83,104,121,132,136,138,141,173,177,186]}$. & $15 / 182$ & $\begin{array}{l}\text { Previous } \\
\text { clinical trial } \\
\text { experience }\end{array}$ & F \\
\hline Religious & $\begin{array}{l}\text { The degree of matching between research and religious influences compliance and retention. } \\
{[26,34,54,63,65,125,131,146,147,152,189]}\end{array}$ & $11 / 182$ & Insurance & $\mathrm{H}$ \\
\hline Memory & People who have good memory may have higher compliance and retention $[32,62,66,78,92,107,115,119,144,189]$ & $10 / 182$ & $\begin{array}{l}\text { The level of } \\
\text { pressure }\end{array}$ & 7 \\
\hline Physique & The better the physique, the higher the compliance and retention ${ }^{[16,36,37,48,82,107,131,177,189]}$ & $9 / 182$ & $\begin{array}{l}\text { Desire for } \\
\text { pregnancy }\end{array}$ & \\
\hline Legal & Patients with legal concepts may have higher compliance and retention ${ }^{[12,66,80,90,117,141,171]}$ & $7 / 182$ & Mobility & 1 \\
\hline Social position & People who have high social position may have higher compliance and retention ${ }^{[12,49,120,123,157,158]}$. & $6 / 182$ & $\begin{array}{l}\text { Use of illicit } \\
\text { drugs }\end{array}$ & 1 \\
\hline $\begin{array}{l}\text { Lost or stolen } \\
\text { drugs }\end{array}$ & Lost or stolen drugs may reduce the compliance and retention ${ }^{[44,119,185,186]}$ & $4 / 182$ & $\begin{array}{l}\text { Morbidly } \\
\text { obese }\end{array}$ & 1 \\
\hline & $\mathrm{D}$ & ase & & \\
\hline $\begin{array}{l}\text { Patient's } \\
\text { condition* }\end{array}$ & $\begin{array}{l}\text { Patient with severe illness have higher compliance and retention than those with less severe illness. But they may also } \\
\text { withdraw due to the worsening of their } \\
\text { condition }[17,24,31,33,36,47,48,56,57,59,64,70,72,78,81,93,97,102,105,109,119,123,134,135,136,140,146,150,151,156,157,161,170,172,173,178,179,182,185]\end{array}$ & $39 / 182$ & $\begin{array}{l}\text { Types of } \\
\text { diseases }\end{array}$ & \\
\hline $\begin{array}{l}\text { Attitude } \\
\text { towards disease }\end{array}$ & $\begin{array}{l}\text { People who have positive attitude to disease may have higher compliance and } \\
\text { retention }[16,35,36,45,74,97,109,118,119,132,142,145,146,173,178,189]\end{array}$ & $17 / 182$ & $\begin{array}{l}\text { Wanting more } \\
\text { information } \\
\text { about their } \\
\text { illness }\end{array}$ & \\
\hline
\end{tabular}

Environment

\begin{tabular}{|c|c|c|c|c|}
\hline $\begin{array}{l}\text { Support from } \\
\text { surrounding } \\
\text { people }\end{array}$ & $\begin{array}{l}\text { The more support from surrounding people (family, friends, patient groups), the higher the compliance and retention. } \\
{[19,20,23,25,28,29,31,32,36,37,39,48,50,54,60,61,63-65,73,74,76,78,80-82,85,87-90,93,97,100,102,105,107,108,112-114,116,117,123,124,127,131,136,140-} \\
145,147,149,150,153,157,159,160,161,165,166,170,171,174,178,183,186,189]\end{array}$ & $71 / 182$ & Traffic & $\begin{array}{l}\mathrm{T} \\
\mathrm{r} \\
9\end{array}$ \\
\hline Distance & $\begin{array}{l}\text { Patients who live closer to the study site have higher compliance and } \\
\text { retention }{ }^{[12,16,18,29,33,36,37,44,47,48,50,58,61,64,67,69,78,81,85,87,88,92,93,97,103,105,107,108,109,112-} \\
114,117,119,127,133,137,146,147,153,157,160,161,164,165,177,186]\end{array}$ & $46 / 182$ & $\begin{array}{l}\text { The } \\
\text { environment } \\
\text { of treatment }\end{array}$ & $\begin{array}{l}\mathrm{T} \\
\mathrm{a} \\
1\end{array}$ \\
\hline $\begin{array}{l}\text { Support from } \\
\text { private doctors }\end{array}$ & $\begin{array}{l}\text { The more support from private doctors, the higher the compliance and } \\
\text { retention }\end{array}$ & $23 / 182$ & Media & $\bar{F}$ \\
\hline
\end{tabular}

\begin{tabular}{l|l} 
Safety concerns & $\begin{array}{l}\text { The higher the security, the higher the compliance and retention } \\
6311-13,14,17,22,30,31,35,40,41,48,50,53,55,60,61-\end{array}$ \\
$63,66,67,73,74,78,80,81,83,87,94,96,102,105,107,112,119,120,124,126,135,138,139,141,147,152,153,160,165-167,170,171,174,175,178-180,185,187,189]$
\end{tabular} 


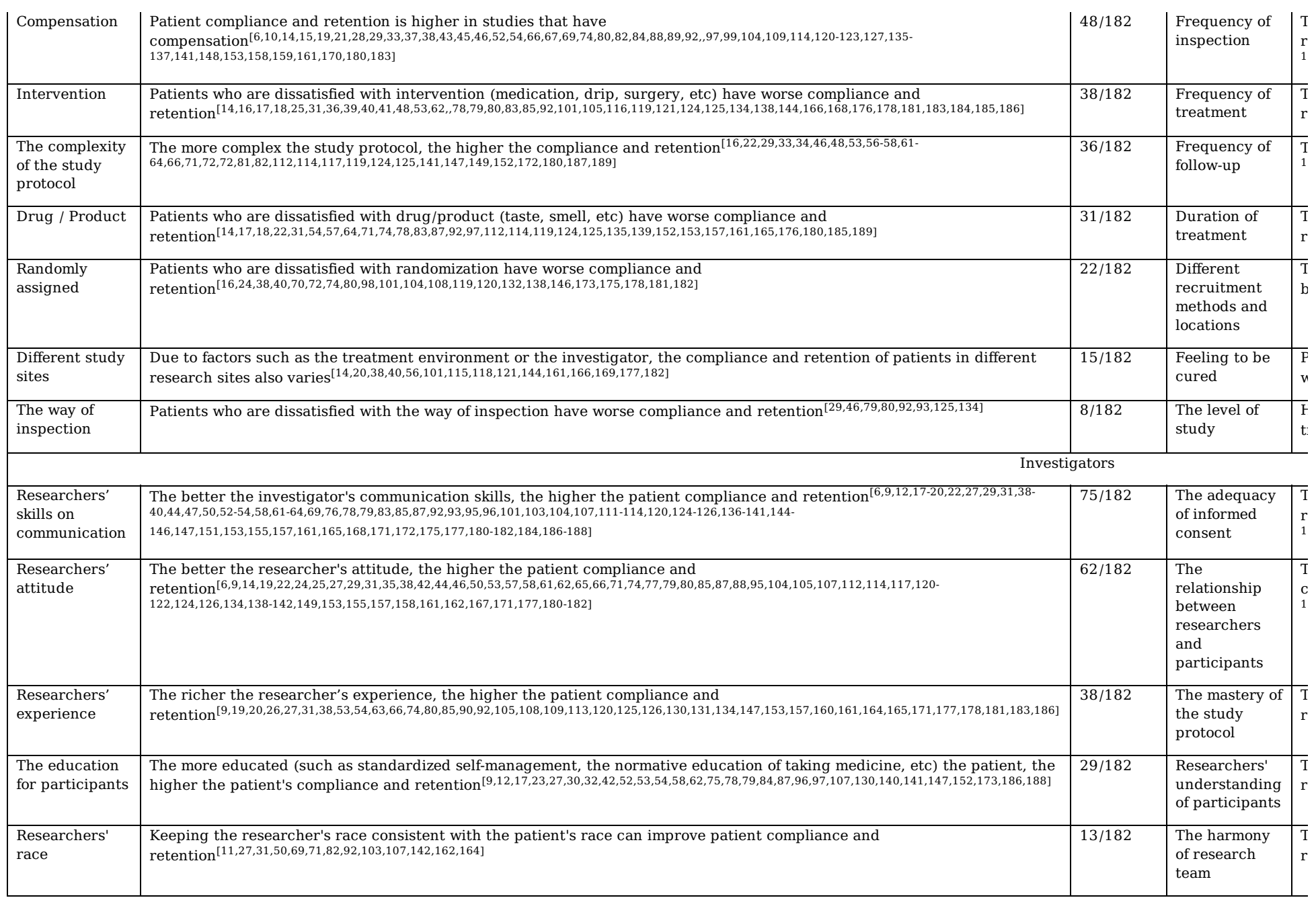

*Explanations derived from information rich studies

Space constraints inhibit the provision of all references. Some references are provided as examples.

Table.2 Potential strategies to improve compliance and retention 


\begin{tabular}{|c|c|c|}
\hline Potential Strategies & Frequency & Potential Strategies \\
\hline \multicolumn{3}{|l|}{ The phase of protocol design } \\
\hline $\begin{array}{l}\text { Develop simple and convenient research or questionnaire design to make them conform to the patient's lifestyle }{ }^{[16,19,20,22-} \\
24,26,33-35,44,45,49,52,54,56,66,69,71,73,74,80,88,89,92,97,105,111,114,117,132,136,143,150,153,156,157,162,165,166,176,177,179,189]\end{array}$ & $45 / 182$ & $\begin{array}{l}\text { Training researchers in advance }(\text { such } \\
{[9,19,26,31,38,53,54,63,66,74,80,90,113,120,130}\end{array}$ \\
\hline 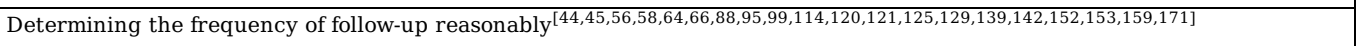 & $21 / 182$ & Recruiting full-time researchers ${ }^{[13,26,2}$ \\
\hline Determining outcomes reasonably $[12,29,31,53,58,97,132,153,174,177]$ & $10 / 182$ & Improving the screening table based o \\
\hline Conducting Nominal Group Meeting to explore measures to improve compliance ${ }^{[11,27,31,32,47,58,107[132,171,186]}$ & $10 / 182$ & Considering the compliance, determini \\
\hline Reducing the frequency of harmful inspection (such as blood draws, etc) ${ }^{[14,16,31,44,52,73,79,92,121]}$ & $9 / 182$ & Considering the rate of dropout when \\
\hline Providing multiple forms of research documents (online or on-site) ${ }^{[16,39,104,153]}$ & $4 / 182$ & Reducing the number of research files \\
\hline Setting up a methodology team to explore measures to improve compliance ${ }^{[80,100,117]}$ & $3 / 182$ & Making full use of predictive factors ${ }^{[53}$ \\
\hline \multicolumn{3}{|l|}{ The phase of recruitment and informed consent } \\
\hline $\begin{array}{l}\text { Full implementation of informed consent(safety concerns, effect, study protocol, the time they may take,etc) } \\
{[14,18,19,22,25,46,53,55,57,64,66,74,78-81,83,87,88,92,93,95-97,107,108,113,114,117,119,120,121,124-} \\
126,132,136,139,140,141,147,149,152,153,157,162,165,167,170,172,176,180,181,186]\end{array}$ & $54 / 182$ & $\begin{array}{l}\text { Expanding the channels of } \\
\text { recruitment } \\
188,189]\end{array}$ \\
\hline Pre-compliance assessment ${ }^{[14,22,25,33-35,45,46,51,55,56,64,66,67,71,72,78-80,91-93,97,108,113,114,125,134,141,147,157,162,165,167,173,176,179]}$ & $37 / 182$ & Emphasizing participants' contribution \\
\hline $\begin{array}{l}\text { Conduct psychological consultation in advance to determine whether the patient is suitable for } \\
\text { enrollment }{ }^{[18,61,62,120,133,140,173]}\end{array}$ & $7 / 182$ & \\
\hline \multicolumn{3}{|l|}{ The phase of the trial implementation period } \\
\hline $\begin{array}{l}\text { Paying attention to the changes on participants' psychological and building good } \\
\text { relationships }{ }^{[6,9,17,19,20,22,25,26,29,32,35,36,38-40,45,46,50,52,53,55,57,61,63,64,69,74,78,79,83,85,87,88,90,92-97,101,103,104,107,112-} \\
114,120,121,125-129,133,134,139-142,146,147,152,153,155,157,158,160-162,167,170,172,180,185,189]\end{array}$ & $75 / 182$ & $\begin{array}{l}\text { Money, gifts and other compensation }{ }^{[6} \\
143,146,149,152,153,155,158-162,170,178,180]\end{array}$ \\
\hline 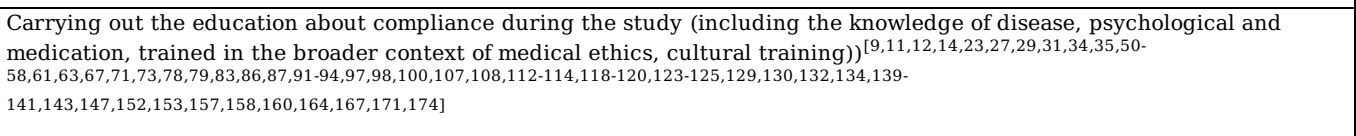 & $65 / 182$ & $\begin{array}{l}\text { Providing online reminder (phone, emé } \\
90,92,93,96,97,100,101,104,108,109,115,120,123\end{array}$ \\
\hline $\begin{array}{l}\text { Recording 3-4 contact information of participants or their family }[12,14,19,20,26,27,31-33,42,44,46,52- \\
54,57,58,61,62,64,67,77,78,88,90,97,101,107,108,112,120,124,125,132,142,143,145,150,152,153,155,157,180,181,186]\end{array}$ & $45 / 182$ & $\begin{array}{l}\text { Establishing the table of follow-up, foll } \\
84,88,89,92,93,96,97,101,103,104,108,120,127,1:\end{array}$ \\
\hline $\begin{array}{l}\text { Flexible study time and } \\
\text { location }[16,19,20,25,26,31,39,44,45,46,54,56,66,69,82,84,85,86,88,89,90,101,103,104,108,118,119,121,123,127,142,146,155,157,160,162,169,170,180,181]\end{array}$ & $40 / 182$ & $\begin{array}{l}\text { Handle adverse reactions timely durin! } \\
42,53,55,63,64,74,78,86,87,92,93,95,107,109,113\end{array}$ \\
\hline $\begin{array}{l}\text { Researchers should adhere to the basic ethical } \\
\text { principles }[9,19,20,29,38,53,59,66,78,80,83,85,88,95,99,107,112,114,120,124,125,129,140,141,146,147,152,153,157,160,172,181]\end{array}$ & $32 / 182$ & $\begin{array}{l}\text { The drug package should be accompan } \\
\text { reactions }[12,31,42,44,52,67,71,75,77,78,80,92 \text {, }\end{array}$ \\
\hline Online data collection $[12,13,30,31,48,75,104,106,107,111,112,124,130,132,144,145,151,164,177,183-189]$ & $26 / 182$ & Fixed researchers and healers ${ }^{[16,25,27,2}$ \\
\hline $\begin{array}{l}\text { Emphasizing the importance of the participants' diary and checking in } \\
\text { time } \\
{[14,22,41,44,52,78,80,92,96,97,103,114,125,129,134,149,152,153,165,170,176]}\end{array}$ & $21 / 182$ & Improving the environment of treatme \\
\hline $\begin{array}{l}\text { At each visit, checking compliance by counting the remaining medications with } \\
\text { participants }{ }^{[14,35,51,66,67,78,80,92,97,114,125,157,167]}\end{array}$ & $13 / 182$ & $\begin{array}{l}\text { Intervention by pharmacists during th } \\
\text { treatment plans, and improving the qu }\end{array}$ \\
\hline $\begin{array}{l}\text { Establishing a record system to dispense medicines and packing medicines according to the } \\
\text { system }^{[14,31,44,50,52,77,96,107,112,124,149,186,187]}\end{array}$ & $13 / 182$ & Intervention by nurses during the stud \\
\hline Reimbursement of traffic ${ }^{[6,12,54,85,103,126,130,159,160,171]}$ & $10 / 182$ & Conducting motivational interviews ${ }^{[17}$ \\
\hline Paying in $\operatorname{cash}^{[19,69,84,104,127,160]}$ & $6 / 182$ & Reporting the effects at any time durin \\
\hline Establishing a record system to remind doing inspection ${ }^{[67,107,186]}$ & $3 / 182$ & \\
\hline
\end{tabular}

\section{Appendix}

Appendix A

\section{Search strategy \\ Pubmed}

\#1 ((adher* OR nonadher* OR complian* OR noncomplian* OR comply OR noncomply)

\#2 (withdrawal OR drop outs OR drop out OR OR attrition OR retention)

$$
\text { \#3 \#1 OR \#2 }
$$

\#4 patient OR participent OR subject

\#5 trial

\#6 \#4 AND \#5

\#7 \#3 AND \#6

\section{EMBASE \& the Cochrane Library}

\#1 ((adher* OR nonadher* OR complian* OR noncomplian* OR comply OR noncomply) \#2 (withdrawal OR drop outs OR drop out OR OR attrition OR retention)

Page $18 / 30$ 
\#3 \#1 OR \#2

\#4 patient adj4 trial OR particip adj4 trial OR subject adj4 trial

\#5 \#3 AND \#4

Chinese National Knowledge Infrastructure Database (CNKI) \& VIP Chinese Science and Technique Journals Database \& Wanfang Database

\#1 Zuncong
\#2 Zunyi
\#3 Yicong
\#4 Baoliu
\#5 Tuoluo
\#6 \#1 OR \#2 OR \#3 OR \#4 OR \#5
\#7 Shoushizhe
\#8 Huanzhe
\#9 Canyuzhe
\#10 \#7 OR \#8 OR \#9
\#11 Shiyan
\#12 Suiji
\#13 Duizhao
\#14 \#11 OR \#12 OR \#13
\#15 \#6 AND \#10 AND \#14

Appendix table 1 The characteristics of included studies ${ }^{[6,11-188]}$ 


\begin{tabular}{|c|c|c|c|c|c|c|c|c|c|}
\hline Study ID & Health conditions specified & Funding & $\begin{array}{l}\text { The } \\
\text { country of } \\
\text { first author }\end{array}$ & $\begin{array}{l}\text { Health } \\
\text { condition }\end{array}$ & Sample population & Design & $\begin{array}{l}\text { Sample } \\
\text { size }\end{array}$ & $\begin{array}{l}\text { Data source } \\
\text { (for } \\
\text { Secondary } \\
\text { studies only) }\end{array}$ & $\begin{array}{l}\text { Performance } \\
\text { of poor } \\
\text { compliance }\end{array}$ \\
\hline Alter M1991 ${ }^{[185]}$ & Smoking & No & USA & $\begin{array}{l}\text { Acute } \\
\text { fatal } \\
\text { disease }\end{array}$ & Adults & $\begin{array}{l}\text { Retrospective } \\
\text { reflection of } \\
\text { RCT }\end{array}$ & 73 & $1 \mathrm{RCT}$ & 1.2 \\
\hline Adubato S $2003^{[171]}$ & Lead-exposure & No & USA & $\begin{array}{l}\text { Chronic } \\
\text { Non-fatal } \\
\text { disease }\end{array}$ & minor & $\begin{array}{l}\text { Retrospective } \\
\text { reflection of } \\
\text { RCT }\end{array}$ & 780 & $1 \mathrm{RCT}$ & 1.2 \\
\hline Avins A L2005[163] & Cancer & Public & USA & $\begin{array}{l}\text { Chronic } \\
\text { fatal } \\
\text { disease }\end{array}$ & Adults & Case report & 1 & $\begin{array}{l}\text { Not } \\
\text { applicable }\end{array}$ & 1.2 \\
\hline $\begin{array}{l}\text { Andrew } \\
\text { Maurice2006 }\end{array}$ & Cancer & No & England & $\begin{array}{l}\text { Chronic } \\
\text { fatal } \\
\text { disease }\end{array}$ & Women & $\begin{array}{l}\text { Implementation } \\
\text { research }\end{array}$ & 100 & $\begin{array}{l}\text { Not } \\
\text { applicable }\end{array}$ & 3 \\
\hline $\begin{array}{l}\text { Anne-Marie } \\
\text { Shields } 2010^{[127]}\end{array}$ & End-stage renal disease & Public & USA & $\begin{array}{l}\text { Chronic } \\
\text { fatal } \\
\text { disease }\end{array}$ & Adults & $\begin{array}{l}\text { Implementation } \\
\text { research }\end{array}$ & 58 & $\begin{array}{l}\text { Not } \\
\text { applicable }\end{array}$ & 1.4 \\
\hline Atassi N2013[109] & Amyotrophic lateral sclerosis & Industrial & USA & $\begin{array}{l}\text { Chronic } \\
\text { non-fatal } \\
\text { disease }\end{array}$ & NR & $\begin{array}{l}\text { Literature } \\
\text { Review }\end{array}$ & 1815 & 55 Studies & 2 \\
\hline Amy Corneli 2015 $5^{[74]}$ & HIV & No & USA & $\begin{array}{l}\text { Chronic } \\
\text { fatal } \\
\text { disease }\end{array}$ & Women & $\begin{array}{l}\text { Mixed methods } \\
\text { approach }\end{array}$ & 312 & $\begin{array}{l}\text { Not } \\
\text { applicable }\end{array}$ & 3 \\
\hline Anjanette A2015 ${ }^{[82]}$ & Major depressive disorder & No & USA & $\begin{array}{l}\text { Chronic } \\
\text { non-fatal } \\
\text { disease }\end{array}$ & NR & Interview & 9 & $\begin{array}{l}\text { Not } \\
\text { applicable }\end{array}$ & 1.2 .4 .5 \\
\hline $\begin{array}{l}\text { Ashley } \\
\text { Salazar2016 }\end{array}$ & $\begin{array}{l}\text { Preterm birth, gestational } \\
\text { diabetes, pregnancy-induced } \\
\text { hypertension, etc }\end{array}$ & Public & USA & $\begin{array}{l}\text { Chronic } \\
\text { non-fatal } \\
\text { disease }\end{array}$ & Pregnant women & $\begin{array}{l}\text { Retrospective } \\
\text { analysis based } \\
\text { on RCTs }\end{array}$ & NR & 9 RCTs & 1.2 \\
\hline Atherton P J2016 ${ }^{[57]}$ & Cancer & public & USA & $\begin{array}{l}\text { Chronic } \\
\text { fatal } \\
\text { disease }\end{array}$ & Adults & $\begin{array}{l}\text { Retrospective } \\
\text { reflection of } \\
\text { RCT }\end{array}$ & 1640 & 14 RCTs & 5 \\
\hline $\begin{array}{l}\text { Anna } \\
\text { Kearney2017 }\end{array}$ & NR & No & England & Unclear & Researchers & Survey & 75 & $\begin{array}{l}\text { Not } \\
\text { applicable }\end{array}$ & 1.2 \\
\hline $\begin{array}{l}\text { Annette } \\
\text { Grape2018[18] }\end{array}$ & Asthma & Public & USA & $\begin{array}{l}\text { Chronic } \\
\text { non-fatal } \\
\text { disease }\end{array}$ & minor & $\begin{array}{l}\text { Implementation } \\
\text { research }\end{array}$ & 373 & $\begin{array}{l}\text { Not } \\
\text { applicable }\end{array}$ & 1.2 \\
\hline Anne Daykin2018 $8^{[19]}$ & NR & Public & England & Unclear & NR & Interview & 22 & $\begin{array}{l}\text { Not } \\
\text { applicable }\end{array}$ & 1.2 \\
\hline $\begin{array}{l}\text { Arame Thiam- } \\
\text { Diouf2018 }\end{array}$ & HIV & Public & USA & $\begin{array}{l}\text { Chronic } \\
\text { fatal } \\
\text { disease }\end{array}$ & NR & $\begin{array}{l}\text { Systematic } \\
\text { review and } \\
\text { meta-analysis }\end{array}$ & 964 & 10 Studies & 1.3 .4 \\
\hline Boyd N F1992[184] & Cancer & Public & Canada & $\begin{array}{l}\text { Chronic } \\
\text { fatal } \\
\text { disease }\end{array}$ & Adults & $\begin{array}{l}\text { Retrospective } \\
\text { reflection of } \\
\text { RCT }\end{array}$ & 280 & $1 \mathrm{RCT}$ & 1.2 \\
\hline $\begin{array}{l}\text { Blumenthal D } \\
\text { S1995 } 182]\end{array}$ & Cancer & Public & USA & $\begin{array}{l}\text { Chronic } \\
\text { fatal } \\
\text { disease }\end{array}$ & Women & $\begin{array}{l}\text { Retrospective } \\
\text { reflection of } \\
\text { RCT }\end{array}$ & 55 & $1 \mathrm{RCT}$ & 1.2 \\
\hline Bender B G1997 $7^{[179]}$ & Asthma & No & USA & $\begin{array}{l}\text { Chronic } \\
\text { Non-fatal } \\
\text { disease }\end{array}$ & Adults and minor & $\begin{array}{l}\text { Retrospective } \\
\text { reflection of } \\
\text { RCT }\end{array}$ & 362 & $1 \mathrm{RCT}$ & 1.2 \\
\hline Bulpitt CJ2001 ${ }^{[174]}$ & Hypertension & Public & England & $\begin{array}{l}\text { Chronic } \\
\text { Non-fatal } \\
\text { disease }\end{array}$ & Seniors & $\begin{array}{l}\text { Retrospective } \\
\text { reflection of } \\
\text { RCT }\end{array}$ & 4695 & $1 \mathrm{RCT}$ & 1.2 \\
\hline Bruce G2003 ${ }^{[170]}$ & Asthma & public & USA & $\begin{array}{l}\text { Chronic } \\
\text { Non-fatal } \\
\text { disease }\end{array}$ & minor & $\begin{array}{l}\text { Retrospective } \\
\text { reflection of } \\
\text { RCT }\end{array}$ & 1041 & $1 \mathrm{RCT}$ & 1.2 \\
\hline $\begin{array}{l}\text { Bradley N } \\
\text { Collins2011[118] }\end{array}$ & Smoking & Public & USA & $\begin{array}{l}\text { Chronic } \\
\text { fatal } \\
\text { disease }\end{array}$ & Pregnant women & $\begin{array}{l}\text { Implementation } \\
\text { research }\end{array}$ & 279 & $\begin{array}{l}\text { Not } \\
\text { applicable }\end{array}$ & 1.2 \\
\hline Brubaker L 2011 [121] & Pelvic floor disorder & No & USA & $\begin{array}{l}\text { Chronic } \\
\text { non-fatal } \\
\text { disease }\end{array}$ & Women & $\begin{array}{l}\text { Focus group } \\
\text { interview }\end{array}$ & 105 & $\begin{array}{l}\text { Not } \\
\text { applicable }\end{array}$ & 1.2 \\
\hline $\begin{array}{l}\text { Busisiwe } \\
\text { Magazi2014 }{ }^{[88]}\end{array}$ & HIV & No & $\begin{array}{l}\text { South } \\
\text { Africa }\end{array}$ & $\begin{array}{l}\text { Chronic } \\
\text { fatal } \\
\text { disease }\end{array}$ & Women & $\begin{array}{l}\text { Focus Group } \\
\text { Interview }\end{array}$ & 102 & $\begin{array}{l}\text { Not } \\
\text { applicable }\end{array}$ & 4 \\
\hline $\begin{array}{l}\text { Boden- } \\
\text { Albala2015[71] }\end{array}$ & Stroke & No & USA & $\begin{array}{l}\text { Chronic } \\
\text { non-fatal } \\
\text { disease }\end{array}$ & Adults & $\begin{array}{l}\text { Mixed methods } \\
\text { approach }\end{array}$ & 93 & $\begin{array}{l}\text { Not } \\
\text { applicable }\end{array}$ & NR \\
\hline $\begin{array}{l}\text { Blaha Robert } \\
\text { Z2015 }^{[72]}\end{array}$ & Traumatic Brain Injury & No & USA & $\begin{array}{l}\text { Chronic } \\
\text { non-fatal } \\
\text { disease }\end{array}$ & Adolescent & $\begin{array}{l}\text { Implementation } \\
\text { research }\end{array}$ & 132 & $\begin{array}{l}\text { Not } \\
\text { applicable }\end{array}$ & 1.2 \\
\hline Barbro L 2015 [73] & Diabetes & No & $\overline{\text { USA }}$ & $\begin{array}{l}\text { Chronic } \\
\text { non-fatal } \\
\text { disease }\end{array}$ & minor & $\begin{array}{l}\text { Retrospective } \\
\text { reflection of } \\
\text { RCT }\end{array}$ & 8677 & $1 \mathrm{RCT}$ & 1.2 \\
\hline $\begin{array}{l}\text { Babatunde O } \\
\text { A2017 }\end{array}$ & Overweight & Public & USA & $\begin{array}{l}\text { Chronic } \\
\text { non-fatal }\end{array}$ & Seniors & RCT & 412 & $\begin{array}{l}\text { Not } \\
\text { applicable }\end{array}$ & 3.4 \\
\hline
\end{tabular}

Page 20/30 


\begin{tabular}{|c|c|c|c|c|c|c|c|c|c|}
\hline & & & & disease & & & & & \\
\hline $\begin{array}{l}\text { Beishuizen C R } \\
\text { L2017 }\end{array}$ & Age-related diseases & Public & Netherland & $\begin{array}{l}\text { Chronic } \\
\text { non-fatal } \\
\text { disease }\end{array}$ & Seniors & RCT & 2994 & $\begin{array}{l}\text { Not } \\
\text { applicable }\end{array}$ & 3.4 .5 \\
\hline Boada M2018 ${ }^{[34]}$ & Alzheimer & No & Spain & $\begin{array}{l}\text { Chronic } \\
\text { non-fatal } \\
\text { disease }\end{array}$ & NR & $\begin{array}{l}\text { Theoretical } \\
\text { research }\end{array}$ & NR & $\begin{array}{l}\text { Not } \\
\text { applicable }\end{array}$ & 1 \\
\hline $\begin{array}{l}\text { Constance M } \\
2005^{[162]}\end{array}$ & Sexually transmitted infections & No & USA & $\begin{array}{l}\text { Chronic } \\
\text { fatal } \\
\text { disease }\end{array}$ & Women & $\begin{array}{l}\text { Retrospective } \\
\text { reflection of } \\
\text { RCT }\end{array}$ & 376 & $1 \mathrm{RCT}$ & 1.2 \\
\hline $\begin{array}{l}\text { Claire S } \\
\text { Leathem2009 }\end{array}$ & Coronary heart disease & No & Ireland & $\begin{array}{l}\text { Chronic } \\
\text { non-fatal } \\
\text { disease }\end{array}$ & Doctors and patients & Survey & 903 & $\begin{array}{l}\text { Not } \\
\text { applicable }\end{array}$ & 1.3 .4 \\
\hline Chang MW2009[144] & Overweight & public & USA & Unclear & Women & $\begin{array}{l}\text { Retrospective } \\
\text { reflection of } \\
\text { RCT }\end{array}$ & 129 & $1 \mathrm{RCT}$ & 1.4 \\
\hline Cox LE2009 ${ }^{[145]}$ & HIV & Public & USA & $\begin{array}{l}\text { Chronic } \\
\text { fatal } \\
\text { disease }\end{array}$ & Adults & Survey & 238 & $\begin{array}{l}\text { Not } \\
\text { applicable }\end{array}$ & 3.4 \\
\hline CM Zhai2010 $0^{[128]}$ & Heart failure & No & China & $\begin{array}{l}\text { Chronic } \\
\text { fatal } \\
\text { disease }\end{array}$ & NR & RCT & 64 & $\begin{array}{l}\text { Not } \\
\text { applicable }\end{array}$ & 3.4 \\
\hline CC Xia2013 $[105]$ & Stroke & No & China & $\begin{array}{l}\text { Acute } \\
\text { fatal } \\
\text { disease }\end{array}$ & Adults & $\begin{array}{l}\text { Implementation } \\
\text { research }\end{array}$ & 68 & $\begin{array}{l}\text { Not } \\
\text { applicable }\end{array}$ & 1.2 .3 \\
\hline CJ Feng2016 & Diseases of the endocrine system & No & China & $\begin{array}{l}\text { Acute } \\
\text { non-fatal } \\
\text { disease }\end{array}$ & Adults & $\begin{array}{l}\text { Retrospective } \\
\text { reflection of } \\
\text { RCT }\end{array}$ & 410 & 15 RCTs & 1.2 \\
\hline ComeliA 2016 $6^{[60]}$ & HIV & Public & China & $\begin{array}{l}\text { Chronic } \\
\text { fatal } \\
\text { disease }\end{array}$ & Women & Interview & 212 & $\begin{array}{l}\text { Not } \\
\text { applicable }\end{array}$ & 3.4 \\
\hline Chhatre S2018 ${ }^{[24]}$ & Cancer & public & USA & $\begin{array}{l}\text { Chronic } \\
\text { fatal } \\
\text { disease }\end{array}$ & Adults & $\begin{array}{l}\text { Implementation } \\
\text { research }\end{array}$ & 551 & $\begin{array}{l}\text { Not } \\
\text { applicable }\end{array}$ & 1.2 \\
\hline $\begin{array}{l}\text { David C } \\
\text { Mohr1999[175] }\end{array}$ & Multiple sclerosis & No & USA & $\begin{array}{l}\text { Chronic } \\
\text { Non-fatal } \\
\text { disease }\end{array}$ & NR & $\begin{array}{l}\text { Mixed methods } \\
\text { approach }\end{array}$ & 939 & $\begin{array}{l}\text { Not } \\
\text { applicable }\end{array}$ & 1.2 .3 .4 \\
\hline de Bruyn G2004 $4^{[168]}$ & HIV & Public & $\overline{\text { USA }}$ & $\begin{array}{l}\text { Chronic } \\
\text { fatal } \\
\text { disease }\end{array}$ & Adults & $\begin{array}{l}\text { Retrospective } \\
\text { reflection of } \\
\text { RCT }\end{array}$ & 3033 & 48 RCTs & 1.2 \\
\hline $\begin{array}{l}\text { D. } \\
\text { Lindström2010 }\end{array}$ & Smoking & Public & Sweden & $\begin{array}{l}\text { Chronic } \\
\text { fatal } \\
\text { disease }\end{array}$ & Adults & Interview & 30 & $\begin{array}{l}\text { Not } \\
\text { applicable }\end{array}$ & 4 \\
\hline DC Fan2010 ${ }^{[134]}$ & NR & No & China & Unclear & NR & $\begin{array}{l}\text { Theoretical } \\
\text { research }\end{array}$ & NR & $\begin{array}{l}\text { Not } \\
\text { applicable }\end{array}$ & 3.4 \\
\hline DC Fan2010 ${ }^{[135]}$ & NR & No & China & Unclear & NR & $\begin{array}{l}\text { Theoretical } \\
\text { research }\end{array}$ & NR & $\begin{array}{l}\text { Not } \\
\text { applicable }\end{array}$ & 3.4 \\
\hline Deborah A2011 ${ }^{[119]}$ & Tuberculosis prevention trial & No & USA & $\begin{array}{l}\text { Chronic } \\
\text { non-fatal } \\
\text { disease }\end{array}$ & Adults & Interview & 355 & $\begin{array}{l}\text { Not } \\
\text { applicable }\end{array}$ & 1.2 .3 .4 \\
\hline David olds2015[76] & NR & Industrial & $\overline{\text { USA }}$ & Unclear & Adults & $\begin{array}{l}\text { Focus group } \\
\text { interview }\end{array}$ & 5969 & $\begin{array}{l}\text { Not } \\
\text { applicable }\end{array}$ & 1.2 \\
\hline $\begin{array}{l}\text { David A. } \\
\text { Rorie2017 } \\
\text { [39] }\end{array}$ & Hypertension & Public & England & $\begin{array}{l}\text { Chronic } \\
\text { non-fatal } \\
\text { disease }\end{array}$ & NR & $\begin{array}{l}\text { Implementation } \\
\text { research }\end{array}$ & 31695 & $\begin{array}{l}\text { Not } \\
\text { applicable }\end{array}$ & 1.3 \\
\hline Epstein E E1994 $^{[183]}$ & Alcohol addiction & Public & $\overline{\text { USA }}$ & $\begin{array}{l}\text { Chronic } \\
\text { Non-fatal } \\
\text { disease }\end{array}$ & Men & $\begin{array}{l}\text { Retrospective } \\
\text { reflection of } \\
\text { RCT }\end{array}$ & 105 & $1 \mathrm{RCT}$ & 1.2 \\
\hline $\begin{array}{l}\text { Eivind Berge } \\
2016^{[66]}\end{array}$ & Stroke & No & Norway & $\begin{array}{l}\text { Chronic } \\
\text { non-fatal } \\
\text { disease }\end{array}$ & NR & Survey & 46 & $\begin{array}{l}\text { Not } \\
\text { applicable }\end{array}$ & 1.2 \\
\hline Erica EM2016 ${ }^{[68]}$ & Schizophrenia & Public & Canada & $\begin{array}{l}\text { Chronic } \\
\text { non-fatal } \\
\text { disease }\end{array}$ & NR & $\begin{array}{l}\text { Literature } \\
\text { Review }\end{array}$ & NR & 48 Studies & 1.2 \\
\hline $\begin{array}{l}\text { Eleanor Ladd } \\
\text { Schneider } \\
\text { Leavens } 2019^{[10]}\end{array}$ & NR & No & $\overline{\text { USA }}$ & $\begin{array}{l}\text { Chronic } \\
\text { non-fatal } \\
\text { disease }\end{array}$ & NR & $\begin{array}{l}\text { Implementation } \\
\text { research }\end{array}$ & 42 & $\begin{array}{l}\text { Not } \\
\text { applicable }\end{array}$ & 1.2 .3 .4 .5 \\
\hline $\begin{array}{l}\text { Florence } \\
\text { Clark2014 }\end{array}$ & NR & Public & $\overline{U S A}$ & Unclear & Seniors & $\begin{array}{l}\text { Retrospective } \\
\text { reflection of } \\
\text { RCT }\end{array}$ & 460 & $1 \mathrm{RCT}$ & 1.2 \\
\hline Goldman AI1982 $^{[188]}$ & Hypertension & No & USA & $\begin{array}{l}\text { Chronic } \\
\text { Non-fatal } \\
\text { disease }\end{array}$ & Adults & $\begin{array}{l}\text { Retrospective } \\
\text { reflection of } \\
\text { RCT }\end{array}$ & 1012 & $1 \mathrm{RCT}$ & 1.2 .3 .4 \\
\hline Grilo C M1998[178] & Panic Disorders & No & $\overline{\text { USA }}$ & $\begin{array}{l}\text { Chronic } \\
\text { Non-fatal } \\
\text { disease }\end{array}$ & Adults & $\begin{array}{l}\text { Retrospective } \\
\text { reflection of } \\
\text { RCT }\end{array}$ & 162 & $1 \mathrm{RCT}$ & 1.2 \\
\hline G Jónasson 1999[176] $^{[17}$ & Asthma & No & Norway & $\begin{array}{l}\text { Chronic } \\
\text { Non-fatal } \\
\text { disease }\end{array}$ & minor & $\begin{array}{l}\text { Retrospective } \\
\text { reflection of } \\
\text { RCT }\end{array}$ & 163 & $1 \mathrm{RCT}$ & 3.4 \\
\hline
\end{tabular}




\begin{tabular}{|c|c|c|c|c|c|c|c|c|c|}
\hline GD Lu2008[153] & NR & No & China & Unclear & NR & $\begin{array}{l}\text { Retrospective } \\
\text { reflection of } \\
\text { RCT }\end{array}$ & 1181 & $\begin{array}{l}\text { Not } \\
\text { applicable }\end{array}$ & 1.2 \\
\hline GD Lu2008 $^{[154]}$ & NR & No & China & Unclear & NR & $\begin{array}{l}\text { Theoretical } \\
\text { research }\end{array}$ & NR & $\begin{array}{l}\text { Not } \\
\text { applicable }\end{array}$ & 3 \\
\hline GD Lu2009[136] & NR & No & China & Unclear & Adults & Survey & 118 & $\begin{array}{l}\text { Not } \\
\text { applicable }\end{array}$ & 3.4 \\
\hline $\begin{array}{l}\text { Guzmn } \\
\text { Anglica2009[142] }\end{array}$ & Overweight & No & USA & Unclear & minor & RCT & 123 & $\begin{array}{l}\text { Not } \\
\text { applicable }\end{array}$ & 1.4 \\
\hline Grill J D2010 $0^{[129]}$ & Alzheimer & Industrial & USA & $\begin{array}{l}\text { Chronic } \\
\text { fatal } \\
\text { disease }\end{array}$ & NR & $\begin{array}{l}\text { Literature } \\
\text { Review }\end{array}$ & NR & $\begin{array}{l}\text { Not } \\
\text { applicable }\end{array}$ & 4 \\
\hline Gul B R2010[131] & NR & No & USA & Unclear & Adults & $\begin{array}{l}\text { Retrospective } \\
\text { reflection of } \\
\text { RCT }\end{array}$ & NR & $\begin{array}{l}\text { Not } \\
\text { applicable }\end{array}$ & 1.2 \\
\hline $\begin{array}{l}\text { Gatehouse C } \\
\text { S2012 }\end{array}$ & Oral ulcer & Industrial & USA & $\begin{array}{l}\text { Chronic } \\
\text { non-fatal } \\
\text { disease }\end{array}$ & Adults & $\begin{array}{l}\text { Retrospective } \\
\text { reflection of } \\
\text { RCT }\end{array}$ & 160 & $1 \mathrm{RCT}$ & 1.2 .3 \\
\hline GX Chen2016 ${ }^{[64]}$ & NR & No & China & Unclear & NR & $\begin{array}{l}\text { Theoretical } \\
\text { research }\end{array}$ & NR & $\begin{array}{l}\text { Not } \\
\text { applicable }\end{array}$ & 3.4 .5 \\
\hline $\begin{array}{l}\text { Grace Cannard } \\
\text { K2018 }\end{array}$ & Parkinson & Industrial & USA & $\begin{array}{l}\text { Chronic } \\
\text { non-fatal } \\
\text { disease }\end{array}$ & Adults & Survey & 29 & $\begin{array}{l}\text { Not } \\
\text { applicable }\end{array}$ & 1.2 \\
\hline $\begin{array}{l}\text { Higginson } \\
\text { Irene2008 }\end{array}$ & $\begin{array}{l}\text { Multiple sclerosis palliative care } \\
\text { service }\end{array}$ & No & England & $\begin{array}{l}\text { Chronic } \\
\text { fatal } \\
\text { disease }\end{array}$ & Adults & Interview & 52 & $\begin{array}{l}\text { Not } \\
\text { applicable }\end{array}$ & 1.2 .3 .4 \\
\hline \begin{tabular}{l|} 
Haleh Sangi- \\
Haghpeykar2009[137]
\end{tabular} & $\begin{array}{l}\text { Cancer/ Chronic obstructive } \\
\text { pulmonary disease/Ashma }\end{array}$ & No & USA & $\begin{array}{l}\text { Chronic } \\
\text { fatal } \\
\text { disease }\end{array}$ & NR & $\begin{array}{l}\text { Retrospective } \\
\text { reflection of } \\
\text { RCT }\end{array}$ & 541 & $1 \mathrm{RCT}$ & 4 \\
\hline HY Liu2009[139] & Digestive diseases & No & China & $\begin{array}{l}\text { Chronic } \\
\text { non-fatal } \\
\text { disease }\end{array}$ & Adults & Survey & 112 & $\begin{array}{l}\text { Not } \\
\text { applicable }\end{array}$ & 3 \\
\hline Hui D2012 & Cancer Palliative Treatment & Public & USA & $\begin{array}{l}\text { Chronic } \\
\text { fatal } \\
\text { disease }\end{array}$ & NR & $\begin{array}{l}\text { Retrospective } \\
\text { reflection of } \\
\text { RCT }\end{array}$ & 1214 & 18 RCTs & 1.2 \\
\hline HB Zhang2016 ${ }^{[58]}$ & Cancer & No & China & Unclear & Adults & $\begin{array}{l}\text { Retrospective } \\
\text { reflection of } \\
\text { RCT }\end{array}$ & 36 & $1 \mathrm{RCT}$ & 1.2 \\
\hline HY fan 2016[61] & Hypertension & Public & China & $\begin{array}{l}\text { Chronic } \\
\text { non-fatal } \\
\text { disease }\end{array}$ & Adults & $\begin{array}{l}\text { Retrospective } \\
\text { reflection of } \\
\text { RCT }\end{array}$ & 614 & 18 RCTs & 1.2 \\
\hline HY Li 2016 $6^{[62]}$ & Cancer & No & China & $\begin{array}{l}\text { Chronic } \\
\text { fatal } \\
\text { disease }\end{array}$ & Adults & $\begin{array}{l}\text { Implementation } \\
\text { research }\end{array}$ & 60 & $\begin{array}{l}\text { Not } \\
\text { applicable }\end{array}$ & 3.4 \\
\hline H Zhang2016 [63] & NR & Public & China & Unclear & NR & $\begin{array}{l}\text { Theoretical } \\
\text { research }\end{array}$ & NR & $\begin{array}{l}\text { Not } \\
\text { applicable }\end{array}$ & 3.4 .5 \\
\hline HM Wang $2017^{[40]}$ & Cancer & No & China & $\begin{array}{l}\text { Chronic } \\
\text { fatal } \\
\text { disease }\end{array}$ & Adults & RCT & 15 & $\begin{array}{l}\text { Not } \\
\text { applicable }\end{array}$ & 5 \\
\hline Henshall C 2018 & Diabetes & Public & England & $\begin{array}{l}\text { Chronic } \\
\text { non-fatal } \\
\text { disease }\end{array}$ & Adults & Interview & 20 & $\begin{array}{l}\text { Not } \\
\text { applicable }\end{array}$ & 1.2 \\
\hline H xiong2018 ${ }^{[26]}$ & NR & No & China & Unclear & Adults & $\begin{array}{l}\text { retrospective } \\
\text { reflection of } \\
\text { RCTs }\end{array}$ & 371 & $\begin{array}{l}\text { Not } \\
\text { applicable }\end{array}$ & 3.4 \\
\hline HL Duan $2018^{[35]}$ & NR & NO & China & Unclear & NR & $\begin{array}{l}\text { Literature } \\
\text { Review }\end{array}$ & NA & $\begin{array}{l}\text { Not } \\
\text { applicable }\end{array}$ & 1 \\
\hline $\begin{array}{l}\text { Jordhøy M S } \\
\text { 1999 }^{[177]}\end{array}$ & Cancer Palliative Treatment & Public & Norway & $\begin{array}{l}\text { Chronic } \\
\text { fatal } \\
\text { disease }\end{array}$ & Adults & Survey & 434 & $\begin{array}{l}\text { Not } \\
\text { applicable }\end{array}$ & 1.2 .3 .4 \\
\hline J Zeng 2003[172] & NR & $\mathrm{NO}$ & China & Unclear & NR & $\begin{array}{l}\text { Theoretical } \\
\text { research }\end{array}$ & NR & $\begin{array}{l}\text { Not } \\
\text { applicable }\end{array}$ & 3 \\
\hline J Xiao2007 $7^{[158]}$ & NR & No & China & Unclear & NR & $\begin{array}{l}\text { Theoretical } \\
\text { research }\end{array}$ & NR & $\begin{array}{l}\text { Not } \\
\text { applicable }\end{array}$ & 3 \\
\hline J Xiong 2011[125] & Asthma & No & China & $\begin{array}{l}\text { Chronic } \\
\text { fatal } \\
\text { disease }\end{array}$ & NR & $\begin{array}{l}\text { Retrospective } \\
\text { reflection of } \\
\text { RCT }\end{array}$ & NR & $1 \mathrm{RCT}$ & 3.4 \\
\hline J Wei2014 ${ }^{[96]}$ & NR & No & China & Unclear & NR & $\begin{array}{l}\text { Theoretical } \\
\text { research }\end{array}$ & NA & $\begin{array}{l}\text { Not } \\
\text { applicable }\end{array}$ & 1.2 \\
\hline Joseph A 2015 [80] & Cancer & No & USA & $\begin{array}{l}\text { Chronic } \\
\text { fatal } \\
\text { disease }\end{array}$ & NR & $\begin{array}{l}\text { Theoretical } \\
\text { research }\end{array}$ & NR & $\begin{array}{l}\text { Not } \\
\text { applicable }\end{array}$ & 1.2 .3 .4 \\
\hline Julia Lawton $2017^{[37]}$ & Diabetes & Public & England & $\begin{array}{l}\text { Chronic } \\
\text { non-fatal } \\
\text { disease }\end{array}$ & Researchers & Interview & 22 & $\begin{array}{l}\text { Not } \\
\text { applicable }\end{array}$ & 1.2 .3 .4 \\
\hline J. Lloyd $2017^{[38]}$ & Overweight & Public & England & $\begin{array}{l}\text { Chronic } \\
\text { non-fatal } \\
\text { disease }\end{array}$ & minor & $\begin{array}{l}\text { Implementation } \\
\text { research }\end{array}$ & 1324 & $\begin{array}{l}\text { Not } \\
\text { applicable }\end{array}$ & 1.4 \\
\hline
\end{tabular}




\begin{tabular}{|c|c|c|c|c|c|c|c|c|c|}
\hline$J J J \operatorname{Jin} 2017^{[50]}$ & Blood disease & No & China & Unclear & NR & $\begin{array}{l}\text { Retrospective } \\
\text { analysis based } \\
\text { on RCTs }\end{array}$ & 200 & 19 RCTs & 3.4 .5 \\
\hline $\begin{array}{l}\text { Joshua } \\
\text { Wynne2018 }\end{array}$ & HIV & No & England & $\begin{array}{l}\text { Chronic } \\
\text { fatal } \\
\text { disease }\end{array}$ & Women & $\begin{array}{l}\text { Implementation } \\
\text { research }\end{array}$ & 322 & $\begin{array}{l}\text { Not } \\
\text { applicable }\end{array}$ & 1.3 .4 \\
\hline JX Tao2018 ${ }^{[30]}$ & Hepatitis & Public & China & $\begin{array}{l}\text { Acute } \\
\text { non-fatal } \\
\text { disease }\end{array}$ & Adults & $\begin{array}{l}\text { Retrospective } \\
\text { analysis based } \\
\text { on RCTs }\end{array}$ & 620 & $1 \mathrm{RCT}$ & 3.4 \\
\hline JH liu 2018[31] & NR & No & China & Unclear & Adults & RCT & 90 & $\begin{array}{l}\text { Not } \\
\text { applicable }\end{array}$ & \begin{tabular}{|l|}
3.4 \\
\end{tabular} \\
\hline J Yang2018 $^{[32]}$ & NR & No & China & Unclear & NR & $\begin{array}{l}\text { Retrospective } \\
\text { analysis based } \\
\text { on RCTs }\end{array}$ & 56 & 4 RCTs & 1.2 \\
\hline $\begin{array}{l}\text { Joanna C } \\
\text { Crocker2018 }\end{array}$ & NR & No & England & Unclear & \begin{tabular}{|l} 
NR \\
\end{tabular} & \begin{tabular}{|l} 
Systematic \\
review and \\
meta-analysis
\end{tabular} & 2222 & 6 Studies & 1.2 \\
\hline JS Liang2019 $9^{[14]}$ & NR & Public & China & Unclear & NR & $\begin{array}{l}\text { retrospective } \\
\text { reflection of } \\
\text { RCTs }\end{array}$ & 82 & 8 RCTs & 3.4 \\
\hline Kvien TK1983 ${ }^{[187]}$ & Arthritis & Industrial & Norway & $\begin{array}{l}\text { Chronic } \\
\text { Non-fatal } \\
\text { disease }\end{array}$ & Adolescent & $\begin{array}{l}\text { Implementation } \\
\text { research }\end{array}$ & 80 & $\begin{array}{l}\text { Not } \\
\text { applicable }\end{array}$ & 3.4 \\
\hline $\begin{array}{l}\text { Kalkhuis-Beam } \\
\text { S2011 }\end{array}$ & Smoking & public & USA & $\begin{array}{l}\text { Chronic } \\
\text { fatal } \\
\text { disease }\end{array}$ & Adolescent & RCT & 710 & $\begin{array}{l}\text { Not } \\
\text { applicable }\end{array}$ & \begin{tabular}{|l|}
1.2 \\
\end{tabular} \\
\hline Koog Y H2013 $[110]$ & Arthritis & NO & Korea & $\begin{array}{l}\text { Chronic } \\
\text { non-fatal } \\
\text { disease }\end{array}$ & NR & $\begin{array}{l}\text { Systematic } \\
\text { review and } \\
\text { meta-analysis }\end{array}$ & 13593 & 266 Studies & 2 \\
\hline Kadam R A2016 [53] & NR & Industrial & India & Unclear & Researchers & \begin{tabular}{|l} 
Survey \\
\end{tabular} & 73 & $\begin{array}{l}\text { Not } \\
\text { applicable }\end{array}$ & 1.2 \\
\hline Kati A K2017 $7^{[42]}$ & Serious mental health problems & No & Finland & $\begin{array}{l}\text { Chronic } \\
\text { non-fatal } \\
\text { disease }\end{array}$ & Adults & RCT & 1139 & $\begin{array}{l}\text { Not } \\
\text { applicable }\end{array}$ & 1.2 \\
\hline $\begin{array}{l}\text { Lynette } \\
\text { Dias2005 }\end{array}$ & Myopia & Public & USA & $\begin{array}{l}\text { Chronic } \\
\text { Non-fatal } \\
\text { disease }\end{array}$ & minor & Survey & 446 & $\begin{array}{l}\text { Not } \\
\text { applicable }\end{array}$ & 1.2 \\
\hline LJ Tian2009 $9^{[140]}$ & NR & Public & China & Unclear & NR & Survey & 326 & $\begin{array}{l}\text { Not } \\
\text { applicable }\end{array}$ & NR \\
\hline $\begin{array}{l}\text { Lesley J } \\
\text { Burgess } 2010^{[126]}\end{array}$ & NR & No & $\begin{array}{l}\text { South } \\
\text { Africa }\end{array}$ & Unclear & NR & $\begin{array}{l}\text { Retrospective } \\
\text { reflection of } \\
\text { RCT }\end{array}$ & 1386 & 50 RCTs & 1.2 \\
\hline LJ Burgess 2011[122] & NR & No & $\begin{array}{l}\text { South } \\
\text { Africa }\end{array}$ & Unclear & Adults & Survey & 302 & $\begin{array}{l}\text { Not } \\
\text { applicable }\end{array}$ & 1.2 \\
\hline Lewis AL2013[106] & Smoking & Public & USA & $\begin{array}{l}\text { Chronic } \\
\text { non-fatal } \\
\text { disease }\end{array}$ & Adolescent & $\begin{array}{l}\text { Retrospective } \\
\text { reflection of } \\
\text { RCT }\end{array}$ & 98 & $1 \mathrm{RCT}$ & 7 \\
\hline LP Mai2014 $^{[91]}$ & NR & No & China & Unclear & NR & $\begin{array}{l}\text { Retrospective } \\
\text { reflection of } \\
\text { RCT }\end{array}$ & NR & 10 RCTs & NR \\
\hline Lopes R T 2014 ${ }^{[98]}$ & Major depressive disorder & public & Portugal & $\begin{array}{l}\text { Chronic } \\
\text { non-fatal } \\
\text { disease }\end{array}$ & Adults & RCT & 63 & $\begin{array}{l}\text { Not } \\
\text { applicable }\end{array}$ & 1.2 .3 .4 .5 \\
\hline LangfordD P2015 [75] & Fracture & Public & Canada & $\begin{array}{l}\text { Acute } \\
\text { non-fatal } \\
\text { disease }\end{array}$ & Seniors & RCT & 30 & $\begin{array}{l}\text { Not } \\
\text { applicable }\end{array}$ & 1.2 \\
\hline L Zhang2015 ${ }^{[78]}$ & NR & No & China & Unclear & NR & $\begin{array}{l}\text { Retrospective } \\
\text { reflection of } \\
\text { RCT }\end{array}$ & 1351 & 40 RCTs & 1.2 \\
\hline L Mood2015[81] & Disability & Public & Portland & $\begin{array}{l}\text { Chronic } \\
\text { non-fatal } \\
\text { disease }\end{array}$ & $\begin{array}{l}\text { Persons with physical } \\
\text { disabilities }\end{array}$ & $\begin{array}{l}\text { Literature } \\
\text { Review }\end{array}$ & NR & $\begin{array}{l}\text { Not } \\
\text { applicable }\end{array}$ & 1.2 \\
\hline $\begin{array}{l}\text { Louise } \\
\text { Robinson2016 }{ }^{[65]}\end{array}$ & NR & No & England & Unclear & minor & \begin{tabular}{|l|} 
Systematic \\
review and \\
meta analysis
\end{tabular} & 154 & 28 RCTs & \begin{tabular}{|l|}
1.2 \\
\end{tabular} \\
\hline $\begin{array}{l}\text { Laura A. Novak } \\
2019^{[11]}\end{array}$ & $\begin{array}{l}\text { Post-traumatic stress } \\
\text { disorder(PTSD) }\end{array}$ & No & USA & $\begin{array}{l}\text { Acute } \\
\text { non-fatal } \\
\text { disease }\end{array}$ & Adults & \begin{tabular}{|l} 
Survey \\
\end{tabular} & 666 & $\begin{array}{l}\text { Not } \\
\text { applicable }\end{array}$ & 1.2 \\
\hline Morse EV1991 ${ }^{[186]}$ & HIV & Public & USA & $\begin{array}{l}\text { Chronic } \\
\text { fatal } \\
\text { disease }\end{array}$ & Adults & $\begin{array}{l}\text { Retrospective } \\
\text { reflection of } \\
\text { RCT }\end{array}$ & 40 & $1 \mathrm{RCT}$ & 3.4 \\
\hline $\begin{array}{l}\text { Marion } \\
\text { Good1997[181] }\end{array}$ & NR & Public & USA & Unclear & NR & Case report & 8 & $\begin{array}{l}\text { Not } \\
\text { applicable }\end{array}$ & 1.2 \\
\hline $\begin{array}{l}\text { Mazzuca S } \\
\text { A2004[167] }\end{array}$ & Arthritis & public & $\overline{\text { USA }}$ & $\begin{array}{l}\text { Chronic } \\
\text { Non-fatal } \\
\text { disease }\end{array}$ & Women & $\begin{array}{l}\text { Retrospective } \\
\text { reflection of } \\
\text { RCT }\end{array}$ & 432 & 1 RCT & \begin{tabular}{|l|}
1.2 .3 .4 \\
\end{tabular} \\
\hline Mor M2006 $6^{[160]}$ & Intestinal polyps & No & $\overline{\text { USA }}$ & $\begin{array}{l}\text { Chronic } \\
\text { Non-fatal } \\
\text { disease }\end{array}$ & Adults & \begin{tabular}{|l} 
Survey \\
\end{tabular} & 31 & $\begin{array}{l}\text { Not } \\
\text { applicable }\end{array}$ & \begin{tabular}{|l|}
1.2 \\
\end{tabular} \\
\hline
\end{tabular}

Page 23/30 


\begin{tabular}{|c|c|c|c|c|c|c|c|c|c|}
\hline $\begin{array}{l}\text { Merran } \\
\text { Toerien2009 } \\
{[138]}\end{array}$ & NR & Public & England & Unclear & NR & $\begin{array}{l}\text { Literature } \\
\text { Review }\end{array}$ & NR & $\begin{array}{l}\text { Not } \\
\text { applicable }\end{array}$ & 1.4 \\
\hline Magner R2010 ${ }^{[130]}$ & Diabetes & Public & USA & \begin{tabular}{|l|} 
Chronic \\
fatal \\
disease
\end{tabular} & Adults & $\begin{array}{l}\text { Implementation } \\
\text { research }\end{array}$ & 276 & $\begin{array}{l}\text { Not } \\
\text { applicable }\end{array}$ & 1.4 \\
\hline Murphy E J2013 ${ }^{[102]}$ & Major depressive disorder & Public & USA & \begin{tabular}{|l} 
Chronic \\
non-fatal \\
disease
\end{tabular} & NR & $\begin{array}{l}\text { Retrospective } \\
\text { reflection of } \\
\text { RCT }\end{array}$ & 3222 & $1 \mathrm{RCT}$ & 1.2 .3 .4 .5 \\
\hline $\begin{array}{l}\text { Margaret } \\
\text { Pribulick2013 }\end{array}$ & Cardiovascular disease & Public & USA & \begin{tabular}{|l|} 
Chronic \\
fatal \\
disease
\end{tabular} & Rural women & $\begin{array}{l}\text { Retrospective } \\
\text { reflection of } \\
\text { RCT }\end{array}$ & 167 & $1 \mathrm{RCT}$ & 1.2 .3 \\
\hline Marjorie C2014 ${ }^{[84]}$ & Hearing loss & Public & USA & \begin{tabular}{|l} 
Chronic \\
non-fatal \\
disease
\end{tabular} & Farm operators & RCT & 709 & $\begin{array}{l}\text { Not } \\
\text { applicable }\end{array}$ & 1.2 .4 .5 \\
\hline Mary Fischer2014 ${ }^{[85]}$ & Osteoporosis & Public & USA & \begin{tabular}{|l|} 
Chronic \\
non-fatal \\
disease
\end{tabular} & Women & Interview & 43 & $\begin{array}{l}\text { Not } \\
\text { applicable }\end{array}$ & 3.4 \\
\hline M Yang2015[79] & NR & No & China & Unclear & NR & $\begin{array}{l}\text { Theoretical } \\
\text { research }\end{array}$ & NR & $\begin{array}{l}\text { Not } \\
\text { applicable }\end{array}$ & 2 \\
\hline Miguel AQ2016 ${ }^{[59]}$ & Cocaine dependence & Public & Brazil & \begin{tabular}{|l} 
Chronic \\
non-fatal \\
disease
\end{tabular} & Adults & RCT & 65 & $\begin{array}{l}\text { Not } \\
\text { applicable }\end{array}$ & 1.2 .3 .4 \\
\hline $\begin{array}{l}\text { Megan } \\
\text { Comerford2017 }\end{array}$ & Hepatitis & Industrial & India & \begin{tabular}{|l} 
Chronic \\
non-fatal \\
disease
\end{tabular} & Adults & $\begin{array}{l}\text { Retrospective } \\
\text { analysis based } \\
\text { on RCTs }\end{array}$ & 387 & $1 \mathrm{RCT}$ & 1.2 \\
\hline MK Yu2019 $9^{[6]}$ & NR & Public & China & Unclear & NR & $\begin{array}{l}\text { Literature } \\
\text { Review }\end{array}$ & NR & $\begin{array}{l}\text { Not } \\
\text { applicable }\end{array}$ & 1.2 .3 .4 \\
\hline $\begin{array}{l}\text { Natalie A. } \\
\text { Johnson2015[70] }\end{array}$ & Alcohol addiction & No & USA & \begin{tabular}{|l} 
Chronic \\
non-fatal \\
disease
\end{tabular} & Adults & $\begin{array}{l}\text { Retrospective } \\
\text { reflection of } \\
\text { RCT }\end{array}$ & 837 & $1 \mathrm{RCT}$ & 1.2 \\
\hline HS Zhang2013 ${ }^{[108]}$ & Asthma & No & China & \begin{tabular}{|l} 
Chronic \\
Non-fatal \\
disease
\end{tabular} & Adults & $\begin{array}{l}\text { Retrospective } \\
\text { reflection of } \\
\text { RCT }\end{array}$ & 68 & $1 \mathrm{RCT}$ & $1 \llbracket 2 \llbracket 3 \llbracket 4 \llbracket 5$ \\
\hline $\begin{array}{l}\text { Olubukola T Idoko } \\
2014^{[89]}\end{array}$ & NR & No & Gambia & Unclear & minor & $\begin{array}{l}\text { Retrospective } \\
\text { reflection of } \\
\text { RCT }\end{array}$ & 300 & $1 \mathrm{RCT}$ & 1.2 .4 .5 \\
\hline Okhomina V2018 ${ }^{[27]}$ & Cardiovascular disease & Public & USA & \begin{tabular}{|l|} 
Chronic \\
non-fatal \\
disease
\end{tabular} & Adults & Cohort study & 375 & $\begin{array}{l}\text { Not } \\
\text { applicable }\end{array}$ & 1 \\
\hline $\begin{array}{l}\text { Peter M. } \\
\text { Milgrom1 997 }\end{array}$ & Periodontal disease & No & USA & $\begin{array}{l}\text { Chronic } \\
\text { Non-fatal } \\
\text { disease }\end{array}$ & NR & $\begin{array}{l}\text { Implementation } \\
\text { research }\end{array}$ & 70 & $\begin{array}{l}\text { Not } \\
\text { applicable }\end{array}$ & 1.2 .3 .4 \\
\hline P Huang 2014 $4^{[94]}$ & NR & Public & China & Unclear & NR & $\begin{array}{l}\text { Theoretical } \\
\text { research }\end{array}$ & NA & $\begin{array}{l}\text { Not } \\
\text { applicable }\end{array}$ & 1.2 \\
\hline $\begin{array}{l}\text { Plummer M } \\
\text { L2014 }\end{array}$ & HIV & Public & England & \begin{tabular}{|l|} 
Chronic \\
fatal \\
disease
\end{tabular} & Women & $\begin{array}{l}\text { Retrospective } \\
\text { reflection of } \\
\text { RCT }\end{array}$ & 1305 & $1 \mathrm{RCT}$ & 2.3 .5 \\
\hline $\begin{array}{l}\text { Pfammatter A } \\
\text { F2017 }\end{array}$ & NR & No & USA & Unclear & Adults & $\begin{array}{l}\text { Implementation } \\
\text { research }\end{array}$ & 150 & $\begin{array}{l}\text { Not } \\
\text { applicable }\end{array}$ & 1.2 \\
\hline $\begin{array}{l}\text { Paul A. } \\
\text { Leighton } 2017^{[44]}\end{array}$ & Fracture & No & England & \begin{tabular}{|l|} 
Acute \\
non-fatal \\
disease
\end{tabular} & Adults & $\begin{array}{l}\text { Focus Group } \\
\text { Interview }\end{array}$ & 26 & $\begin{array}{l}\text { Not } \\
\text { applicable }\end{array}$ & 1.2 \\
\hline QW Rao2012 $2^{[113]}$ & NR & No & China & Unclear & NR & $\begin{array}{l}\text { Theoretical } \\
\text { research }\end{array}$ & NR & $\begin{array}{l}\text { Not } \\
\text { applicable }\end{array}$ & 3 \\
\hline Q Zhang2014 ${ }^{[92]}$ & NR & No & China & Unclear & NR & $\begin{array}{l}\text { Theoretical } \\
\text { research }\end{array}$ & NA & $\begin{array}{l}\text { Not } \\
\text { applicable }\end{array}$ & 3.4 \\
\hline $\begin{array}{l}\text { Raymond E } \\
\text { G2004 }^{[166]}\end{array}$ & Pregnancy & Public & USA & Unclear & Women & $\begin{array}{l}\text { Retrospective } \\
\text { reflection of } \\
\text { RCT }\end{array}$ & 1514 & $1 \mathrm{RCT}$ & 1.2 \\
\hline $\begin{array}{l}\text { Russell E } \\
\text { Glasgow2007 }\end{array}$ & Overweight & No & USA & \begin{tabular}{|l|} 
Chronic \\
Non-fatal \\
disease
\end{tabular} & Adults & $\begin{array}{l}\text { Retrospective } \\
\text { reflection of } \\
\text { RCT }\end{array}$ & 2311 & $1 \mathrm{RCT}$ & 1.2 \\
\hline Romina Kim 2014 $4^{[90]}$ & Smoking & public & USA & \begin{tabular}{|l|} 
Chronic \\
non-fatal \\
disease
\end{tabular} & $\begin{array}{l}\text { Patients with mental } \\
\text { illness }\end{array}$ & $\begin{array}{l}\text { Retrospective } \\
\text { reflection of } \\
\text { RCT }\end{array}$ & 100 & $1 \mathrm{RCT}$ & 1.2 .3 .4 \\
\hline $\begin{array}{l}\text { Robert S. } \\
\text { Ware2017 }\end{array}$ & Intellectual disability & Public & USA & \begin{tabular}{|l|} 
Chronic \\
non-fatal \\
disease
\end{tabular} & $\begin{array}{l}\text { Adolescent with } \\
\text { mental retardation }\end{array}$ & RCT & 556 & $\begin{array}{l}\text { Not } \\
\text { applicable }\end{array}$ & 1.2 \\
\hline $\begin{array}{l}\text { Rachel } \\
\text { Schoor2018 }\end{array}$ & Multiple sclerosis & Public & USA & \begin{tabular}{|l} 
Chronic \\
non-fatal \\
disease
\end{tabular} & Adults & $\begin{array}{l}\text { Motivational } \\
\text { interview }\end{array}$ & 75 & $\begin{array}{l}\text { Not } \\
\text { applicable }\end{array}$ & 1.2 .3 .4 \\
\hline Rosalind J 2018[25] & Ebola & public & USA & $\begin{array}{l}\text { Acute } \\
\text { fatal } \\
\text { disease }\end{array}$ & $\begin{array}{l}\text { Healthcare providers, } \\
\text { or Ebola front-line } \\
\text { workers }\end{array}$ & RCT & 7979 & $\begin{array}{l}\text { Not } \\
\text { applicable }\end{array}$ & 3 \\
\hline $\begin{array}{l}\text { Rios-Romenets } \\
\text { S2018 }\end{array}$ & Alzheimer & Public & Colombia & $\begin{array}{l}\text { Chronic } \\
\text { non-fatal } \\
\text { disease }\end{array}$ & Adults & $\begin{array}{l}\text { Implementation } \\
\text { research }\end{array}$ & 252 & $\begin{array}{l}\text { Not } \\
\text { applicable }\end{array}$ & 1.2 \\
\hline $\begin{array}{l}\text { Sonawalla Shamsah } \\
\text { B2002 }\end{array}$ & Major depressive disorder & No & USA & \begin{tabular}{|l|} 
Chronic \\
Non-fatal
\end{tabular} & Adults & $\begin{array}{l}\text { Retrospective } \\
\text { reflection of }\end{array}$ & 119 & $1 \mathrm{RCT}$ & 1.2 \\
\hline
\end{tabular}

Page 24/30 


\begin{tabular}{|c|c|c|c|c|c|c|c|c|c|}
\hline & & & & disease & & RCT & & & \\
\hline Sears S R2003 ${ }^{[169]}$ & Cancer & Public & USA & $\begin{array}{l}\text { Chronic } \\
\text { fatal } \\
\text { disease }\end{array}$ & Women & $\begin{array}{l}\text { Retrospective } \\
\text { reflection of } \\
\text { RCT }\end{array}$ & 558 & $1 \mathrm{RCT}$ & 1.2 \\
\hline Steven K2005 $5^{[164]}$ & Major depressive disorder & Public & Portland & $\begin{array}{l}\text { Chronic } \\
\text { Non-fatal } \\
\text { disease }\end{array}$ & Adults & Interview & 31 & $\begin{array}{l}\text { Not } \\
\text { applicable }\end{array}$ & 1.2 .3 .4 \\
\hline Siddiqi A A2008 ${ }^{[152]}$ & Cancer & $\mathrm{NO}$ & USA & $\begin{array}{l}\text { Acute } \\
\text { fatal } \\
\text { disease }\end{array}$ & Adults & $\begin{array}{l}\text { Implementation } \\
\text { research }\end{array}$ & 713 & $\begin{array}{l}\text { Not } \\
\text { applicable }\end{array}$ & 1.2 \\
\hline SS Bull2008 $^{[155]}$ & HIV & industrial & USA & $\begin{array}{l}\text { Chronic } \\
\text { fatal } \\
\text { disease }\end{array}$ & NR & $\begin{array}{l}\text { Implementation } \\
\text { research }\end{array}$ & 2623 & $\begin{array}{l}\text { Not } \\
\text { applicable }\end{array}$ & 1.2 \\
\hline SX Wang2009[141] & NR & Public & China & Unclear & Adults & Survey & 632 & \begin{tabular}{|l|} 
Not \\
applicable
\end{tabular} & 1.2 \\
\hline SM Xue 2009[149] & Orthopaedics & $\mathrm{NO}$ & China & $\begin{array}{l}\text { Chronic } \\
\text { non-fatal } \\
\text { disease }\end{array}$ & NR & $\begin{array}{l}\text { Theoretical } \\
\text { research }\end{array}$ & NR & $\begin{array}{l}\text { Not } \\
\text { applicable }\end{array}$ & 3 \\
\hline $\begin{array}{l}\text { Sharika Gappoo } \\
2009^{[150]}\end{array}$ & HIV & No & $\begin{array}{l}\text { South } \\
\text { Africa }\end{array}$ & $\begin{array}{l}\text { Chronic } \\
\text { fatal } \\
\text { disease }\end{array}$ & Women & $\begin{array}{l}\text { Implementation } \\
\text { research }\end{array}$ & 5045 & \begin{tabular}{|l|} 
Not \\
applicable
\end{tabular} & 1.2 \\
\hline $\begin{array}{l}\text { Sue } \\
\text { Penckofer2011 }\end{array}$ & Diabetes & No & USA & $\begin{array}{l}\text { Chronic } \\
\text { non-fatal } \\
\text { disease }\end{array}$ & Women & $\begin{array}{l}\text { Theoretical } \\
\text { research }\end{array}$ & NR & $\begin{array}{l}\text { Not } \\
\text { applicable }\end{array}$ & 1.2 .3 .4 \\
\hline $\begin{array}{l}\text { S } \\
\text { Knippschild2013 }{ }^{[99]}\end{array}$ & Cataract & No & Germany & $\begin{array}{l}\text { Chronic } \\
\text { non-fatal } \\
\text { disease }\end{array}$ & NR & $\begin{array}{l}\text { Literature } \\
\text { Review }\end{array}$ & 2834 & 18 Studies & 1.2 .4 .5 \\
\hline SY Liu2013 $3^{[107]}$ & Cancer & No & China & $\begin{array}{l}\text { Chronic } \\
\text { fatal } \\
\text { disease }\end{array}$ & Women & $\begin{array}{l}\text { Implementation } \\
\text { research }\end{array}$ & 20 & \begin{tabular}{|l|} 
Not \\
applicable
\end{tabular} & 3.4 \\
\hline Sophie G 2018 ${ }^{[23]}$ & HIV & public & USA & $\begin{array}{l}\text { Chronic } \\
\text { fatal } \\
\text { disease }\end{array}$ & Adults & Interview & 25 & $\begin{array}{l}\text { Not } \\
\text { applicable }\end{array}$ & 1 \\
\hline $\begin{array}{l}\text { Soumya J. } \\
\text { Niranjan2019[9] }\end{array}$ & Cancer & No & USA & $\begin{array}{l}\text { Chronic } \\
\text { fatal } \\
\text { disease }\end{array}$ & Researchers & Interview & 91 & \begin{tabular}{|l|} 
Not \\
applicable
\end{tabular} & 1.2 \\
\hline Ulrich C M2018 ${ }^{[29]}$ & Cancer & Public & USA & $\begin{array}{l}\text { Chronic } \\
\text { fatal } \\
\text { disease }\end{array}$ & Adults & $\begin{array}{l}\text { Retrospective } \\
\text { analysis based } \\
\text { on RCTs }\end{array}$ & 27443 & 134 RCTs & 1.2 \\
\hline $\begin{array}{l}\text { Thayabaranathan } \\
\text { T2016 }\end{array}$ & Stroke & No & USA & $\begin{array}{l}\text { Chronic } \\
\text { non-fatal } \\
\text { disease }\end{array}$ & Nurse & Interview & 2 & \begin{tabular}{|l|} 
Not \\
applicable
\end{tabular} & 1.2 \\
\hline Thomas M 2016 ${ }^{[67]}$ & NR & No & USA & Unclear & NR & $\begin{array}{l}\text { Retrospective } \\
\text { reflection of } \\
\text { RCT }\end{array}$ & NR & \begin{tabular}{|l} 
Not \\
applicable
\end{tabular} & 3 \\
\hline Theresa A2017 ${ }^{[45]}$ & Preeclampsia & public & $\begin{array}{l}\text { South } \\
\text { Africa }\end{array}$ & $\begin{array}{l}\text { Chronic } \\
\text { non-fatal } \\
\text { disease }\end{array}$ & Pregnant women & $\begin{array}{l}\text { Implementation } \\
\text { research }\end{array}$ & 1354 & \begin{tabular}{|l} 
Not \\
applicable
\end{tabular} & 3.4 .5 \\
\hline $\begin{array}{l}\text { Victoria } \\
\text { Villacorta2007[156] }\end{array}$ & HIV & Public & Peru & $\begin{array}{l}\text { Chronic } \\
\text { fatal } \\
\text { disease }\end{array}$ & $\begin{array}{l}\text { Esquineros/Men who } \\
\text { have sex only with men } \\
\text { /Movidas }\end{array}$ & $\begin{array}{l}\text { Implementation } \\
\text { research }\end{array}$ & 1263 & \begin{tabular}{|l} 
Not \\
applicable
\end{tabular} & 1.2 \\
\hline Vellas B2012 [115] & Alzheimer & Public & France & $\begin{array}{l}\text { Chronic } \\
\text { fatal } \\
\text { disease }\end{array}$ & NR & $\begin{array}{l}\text { Theoretical } \\
\text { articles }\end{array}$ & NR & $\begin{array}{l}\text { Not } \\
\text { applicable }\end{array}$ & 1.2 \\
\hline V C Brueton2013 ${ }^{[104]}$ & NR & No & England & Unclear & Researchers & Interview & 29 & \begin{tabular}{|l|} 
Not \\
applicable
\end{tabular} & 1.2 \\
\hline V C Brueton2015 $5^{[69]}$ & Smoking/Headache/Asthma, etc & Public & England & $\begin{array}{l}\text { Chronic } \\
\text { non-fatal } \\
\text { disease }\end{array}$ & NR & $\begin{array}{l}\text { Systematic } \\
\text { review and } \\
\text { meta-analysis }\end{array}$ & 4751 & 38 Studies & 1.2 \\
\hline Warner E T2013 [101] & Overweight/Hypertension & Public & USA & $\begin{array}{l}\text { Chronic } \\
\text { non-fatal } \\
\text { disease }\end{array}$ & Adults & $\begin{array}{l}\text { Implementation } \\
\text { research }\end{array}$ & 474 & \begin{tabular}{|l|} 
Not \\
applicable
\end{tabular} & 1.2 .4 .5 \\
\hline W Wang2014 $4^{[86]}$ & $\begin{array}{l}\text { Chronic obstructive pulmonary } \\
\text { disease }\end{array}$ & No & China & Unclear & Seniors & RCT & 150 & $\begin{array}{l}\text { Not } \\
\text { applicable }\end{array}$ & 3 \\
\hline $\begin{array}{l}\text { Wenke } \\
\text { Zheng2014 }\end{array}$ & NR & No & China & Unclear & NR & $\begin{array}{l}\text { Retrospective } \\
\text { reflection of } \\
\text { RCT }\end{array}$ & NR & $\begin{array}{l}\text { Not } \\
\text { applicable }\end{array}$ & 3.4 \\
\hline Wisk LE2019 ${ }^{[13]}$ & Diabetes & Industrial & USA & $\begin{array}{l}\text { Chronic } \\
\text { non-fatal } \\
\text { disease }\end{array}$ & College students & Survey & 227 & \begin{tabular}{|l|} 
Not \\
applicable
\end{tabular} & 1.2 \\
\hline X Zhang2009 $9^{[146]}$ & NR & No & China & Unclear & NR & $\begin{array}{l}\text { Theoretical } \\
\text { research }\end{array}$ & NA & \begin{tabular}{|l|} 
Not \\
applicable
\end{tabular} & 3 \\
\hline XX Wang 2009 $9^{[147]}$ & NR & Public & China & Unclear & NR & $\begin{array}{l}\text { Theoretical } \\
\text { research }\end{array}$ & NA & \begin{tabular}{|l|} 
Not \\
applicable
\end{tabular} & 3 \\
\hline XN wang $2011^{[124]}$ & Stroke & No & China & $\begin{array}{l}\text { Acute } \\
\text { non-fatal } \\
\text { disease }\end{array}$ & Adults & RCT & 92 & \begin{tabular}{|l|} 
Not \\
applicable
\end{tabular} & 1.3 \\
\hline XW Qiao2014 ${ }^{[87]}$ & Respiratory diseases & No & China & $\begin{array}{l}\text { Chronic } \\
\text { non-fatal }\end{array}$ & Adults & Interview & 52 & \begin{tabular}{|l|} 
Not \\
applicable
\end{tabular} & 1.2 .4 .5 \\
\hline
\end{tabular}

Page 25/30 


\begin{tabular}{|c|c|c|c|c|c|c|c|c|c|}
\hline & & & & disease & & & & & \\
\hline XX wang $2015^{[77]}$ & \begin{tabular}{|l|} 
Cancer \\
\end{tabular} & No & China & $\begin{array}{l}\text { Chronic } \\
\text { fatal } \\
\text { disease }\end{array}$ & Adults & $\begin{array}{l}\text { Single-arm } \\
\text { clinical } \\
\text { research }\end{array}$ & 80 & $\begin{array}{l}\text { Not } \\
\text { applicable }\end{array}$ & NR \\
\hline YP Bao2009 ${ }^{[148]}$ & \begin{tabular}{|l|}
$\mathrm{NR}$ \\
\end{tabular} & \begin{tabular}{|l} 
Public \\
\end{tabular} & \begin{tabular}{|l} 
China \\
\end{tabular} & Unclear & NR & \begin{tabular}{|l} 
Literature \\
Review
\end{tabular} & 2831 & 18 RCTs & 1.4 \\
\hline YJ Huang $2010^{[133]}$ & \begin{tabular}{|l|} 
Cancer \\
\end{tabular} & No & China & $\begin{array}{l}\text { Chronic } \\
\text { fatal } \\
\text { disease }\end{array}$ & Adults & \begin{tabular}{|l|} 
Interview \\
\end{tabular} & 20 & $\begin{array}{l}\text { Not } \\
\text { applicable }\end{array}$ & 3.4 \\
\hline YY Kou 2012 $2^{[112]}$ & Cancer & No & China & $\begin{array}{l}\text { Chronic } \\
\text { fatal } \\
\text { disease }\end{array}$ & Adults & \begin{tabular}{|l|}
$\begin{array}{l}\text { Implementation } \\
\text { research }\end{array}$ \\
\end{tabular} & 68 & $\begin{array}{l}\text { Not } \\
\text { applicable }\end{array}$ & 2.3 .4 \\
\hline YM Hu2012[114] & \begin{tabular}{|l|} 
NR \\
\end{tabular} & No & China & Unclear & NR & $\begin{array}{l}\text { Retrospective } \\
\text { reflection of } \\
\text { RCT }\end{array}$ & 954 & 48 RCTs & \begin{tabular}{|l|l}
1.3 .4 .5 \\
$r$
\end{tabular} \\
\hline Y zhang2012 $2^{[117]}$ & NR & NO & China & \begin{tabular}{|l|} 
Unclear \\
\end{tabular} & $\mathrm{NR}$ & $\begin{array}{l}\text { Theoretical } \\
\text { research }\end{array}$ & NR & $\begin{array}{l}\text { Not } \\
\text { applicable }\end{array}$ & 3 \\
\hline YG Li2014 ${ }^{[93]}$ & \begin{tabular}{|l|} 
Diabetes \\
\end{tabular} & \begin{tabular}{|l} 
No \\
\end{tabular} & China & $\begin{array}{l}\text { Chronic } \\
\text { non-fatal } \\
\text { disease }\end{array}$ & NR & $\begin{array}{l}\text { Retrospective } \\
\text { reflection of } \\
\text { RCT }\end{array}$ & 51 & 14 RCTs & 1 \\
\hline YG Li2014 $4^{[95]}$ & NR & No & China & Unclear & NR & $\begin{array}{l}\text { Theoretical } \\
\text { research }\end{array}$ & NA & $\begin{array}{l}\text { Not } \\
\text { applicable }\end{array}$ & 1.2 \\
\hline YW Zhang2017[51] & NR & No & China & Unclear & NR & $\begin{array}{l}\text { Retrospective } \\
\text { analysis based } \\
\text { on RCTs }\end{array}$ & 828 & 38 RCTs & 1.2 \\
\hline Y Jin2017 ${ }^{[52]}$ & \begin{tabular}{|l} 
Cancer \\
\end{tabular} & No & China & $\begin{array}{l}\text { Chronic } \\
\text { fatal } \\
\text { disease }\end{array}$ & NR & $\begin{array}{l}\text { Retrospective } \\
\text { analysis based } \\
\text { on RCTs }\end{array}$ & 405 & 24 RCTs & 1.2 \\
\hline YS Xu2018[21] & \begin{tabular}{|l|}
$\mathrm{NR}$ \\
\end{tabular} & No & China & Unclear & NR & \begin{tabular}{|l} 
Survey \\
\end{tabular} & 22 & $\begin{array}{l}\text { Not } \\
\text { applicable }\end{array}$ & 3.4 \\
\hline J Zhang2005 ${ }^{[165]}$ & \begin{tabular}{|l|} 
NR \\
\end{tabular} & No & China & Unclear & NR & $\begin{array}{l}\text { Theoretical } \\
\text { research }\end{array}$ & NR & $\begin{array}{l}\text { Not } \\
\text { applicable }\end{array}$ & 3 \\
\hline ZC Cai2017 $^{[49]}$ & Cancer & No & China & $\begin{array}{l}\text { Chronic } \\
\text { fatal } \\
\text { disease }\end{array}$ & Adults & $\begin{array}{l}\begin{array}{l}\text { Implementation } \\
\text { research }\end{array} \\
\end{array}$ & 70 & $\begin{array}{l}\text { Not } \\
\text { applicable }\end{array}$ & \begin{tabular}{|l|}
3.4 .5 \\
\end{tabular} \\
\hline Zhou Q2019 ${ }^{[12]}$ & Cancer & Public & USA & $\begin{array}{l}\text { Chronic } \\
\text { fatal } \\
\text { disease }\end{array}$ & Adults & Survey & 110 & $\begin{array}{l}\text { Not } \\
\text { applicable }\end{array}$ & 1.2 \\
\hline Zoë C Skea2019 ${ }^{[189]}$ & \begin{tabular}{|l} 
NR \\
\end{tabular} & Public\&Industrial & $\begin{array}{l}\text { United } \\
\text { Kingdom }\end{array}$ & Unclear & NR & \begin{tabular}{|l|} 
Meta- \\
ethnographic \\
synthesis
\end{tabular} & 177804 & 13 RCTs & \begin{tabular}{|l|}
1.2 .3 .4 \\
\end{tabular} \\
\hline
\end{tabular}

Note:

USA: the United States of America

RCT: Randomized controlled trial

Not Reported: NR

Performance of poor compliancel1.Loss of follow-up during the study; 2.Failure to treatment ;3.Non-compliance with medication;4.Non-compliance with attendance appointments;5.Non-compliance with filling out the form; 6. Not reported

\section{Figures}

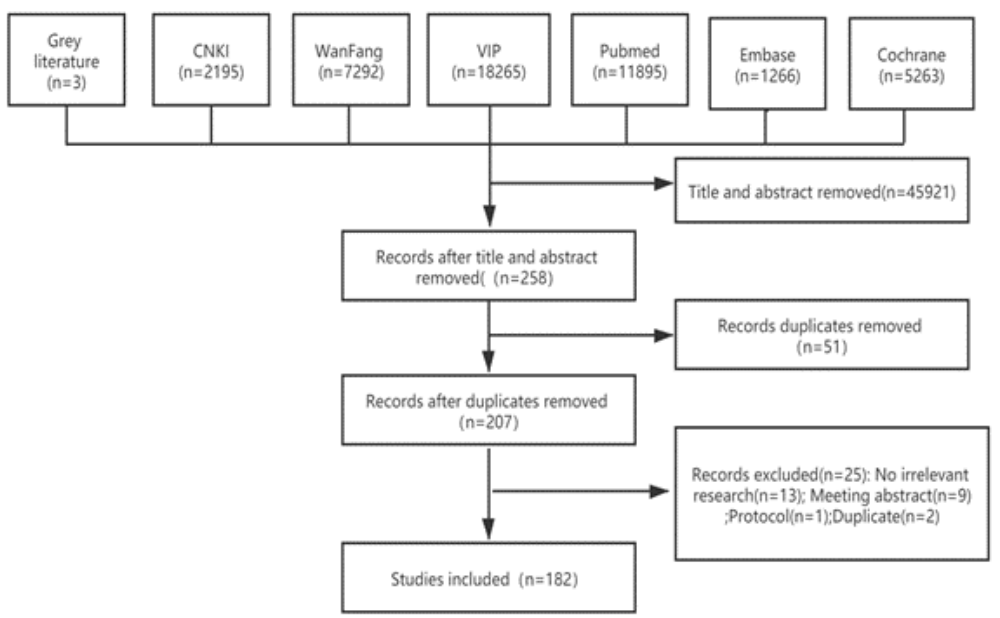

Figure 1 


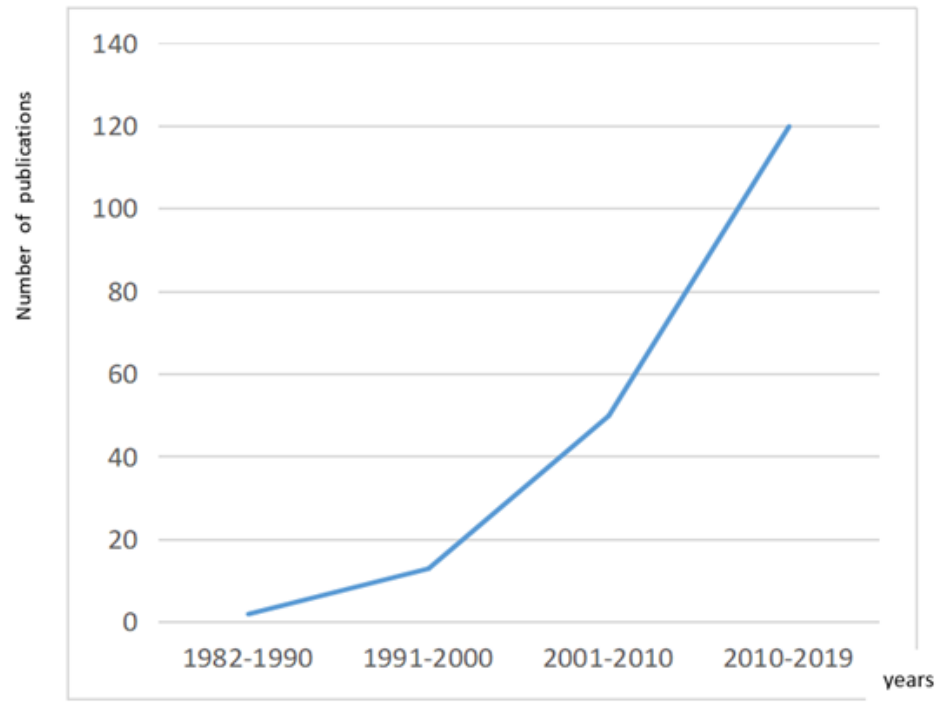

Figure 2

Annual outputs of publications regarding participants compliance and retention in clinical trials from 1982 to 2019.

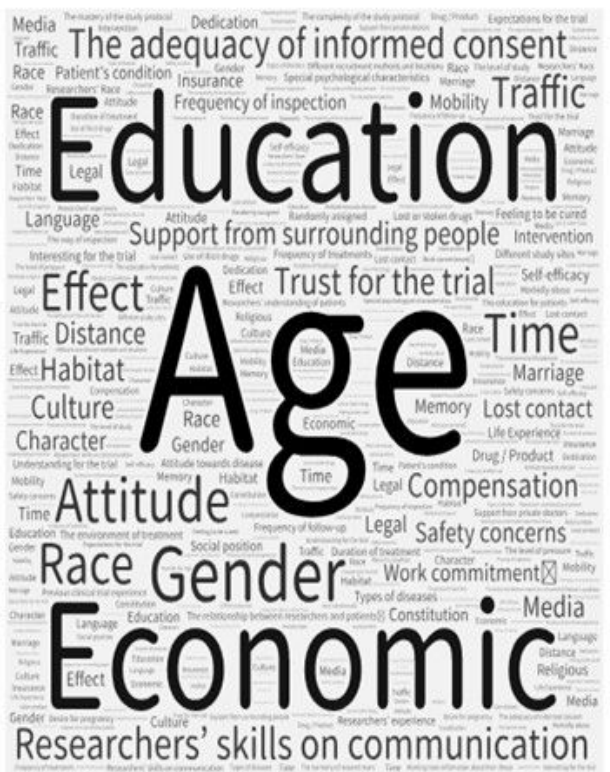

Figure 3

The word cloud about factors affecting the compliance and retention The font size of a word or phrase reflects the frequency of factors in at least two studies. 


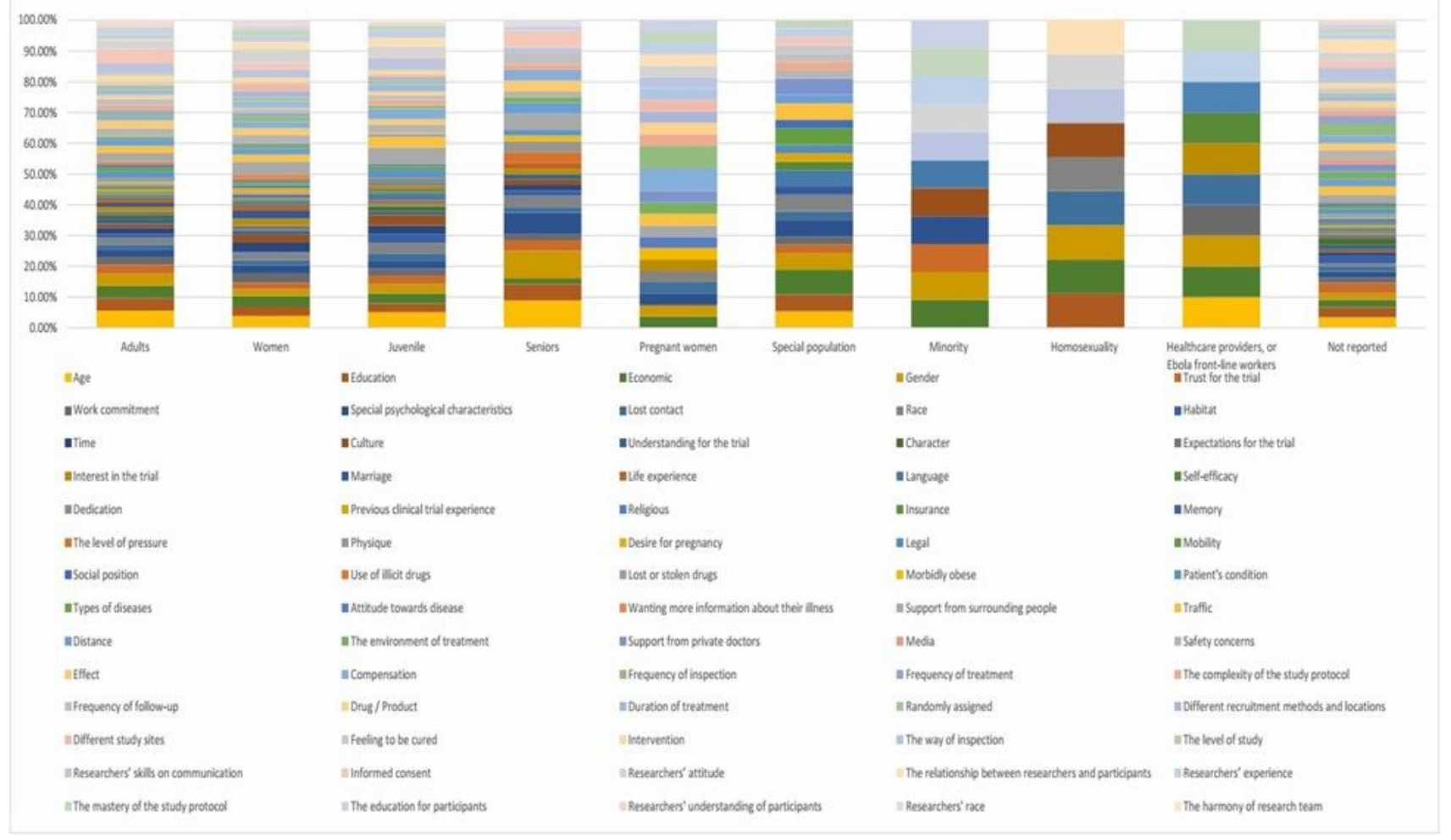

\section{Figure 4}

The process factors in different populations

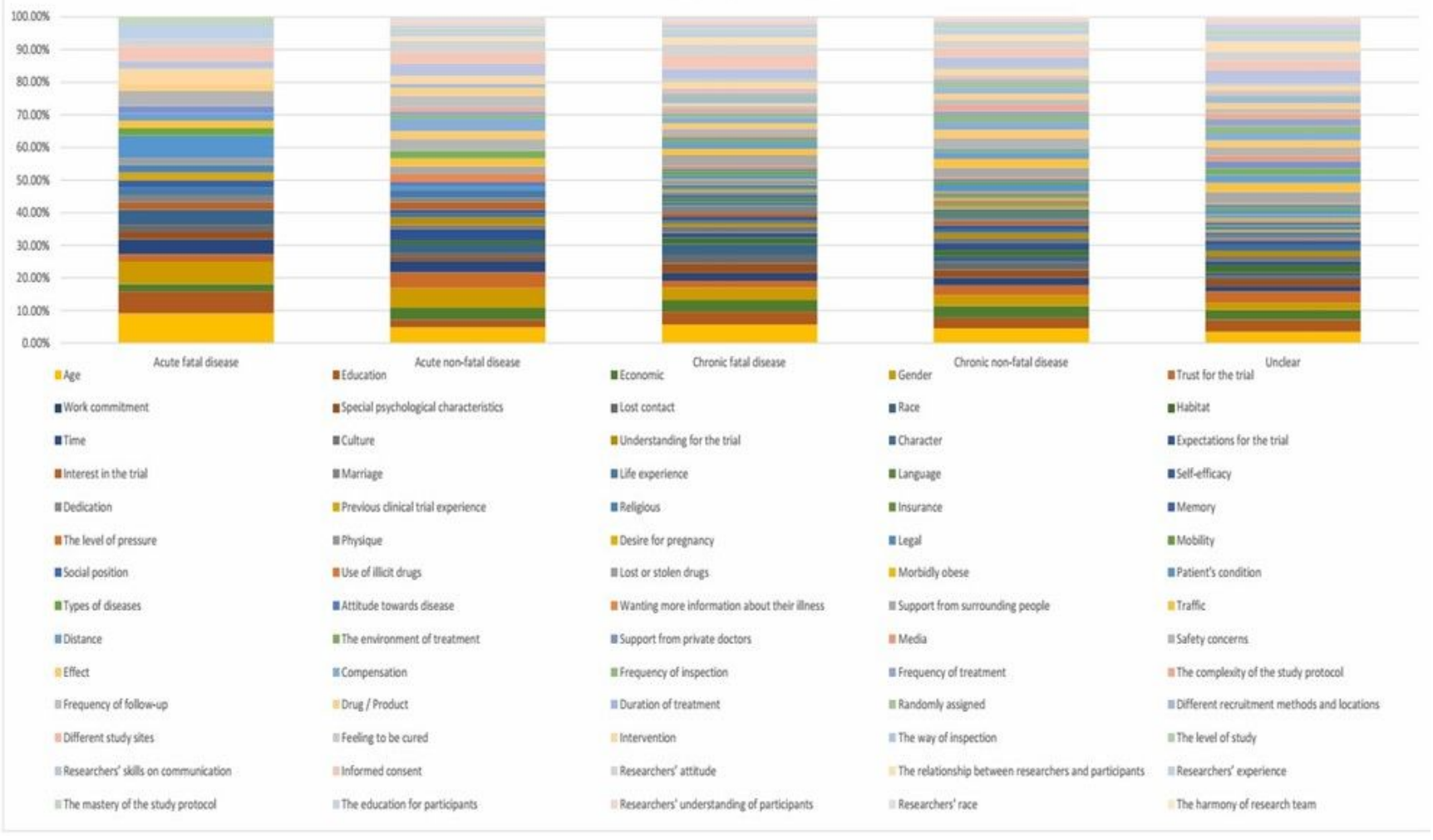

\section{Figure 5}

The process factors in different diseases 


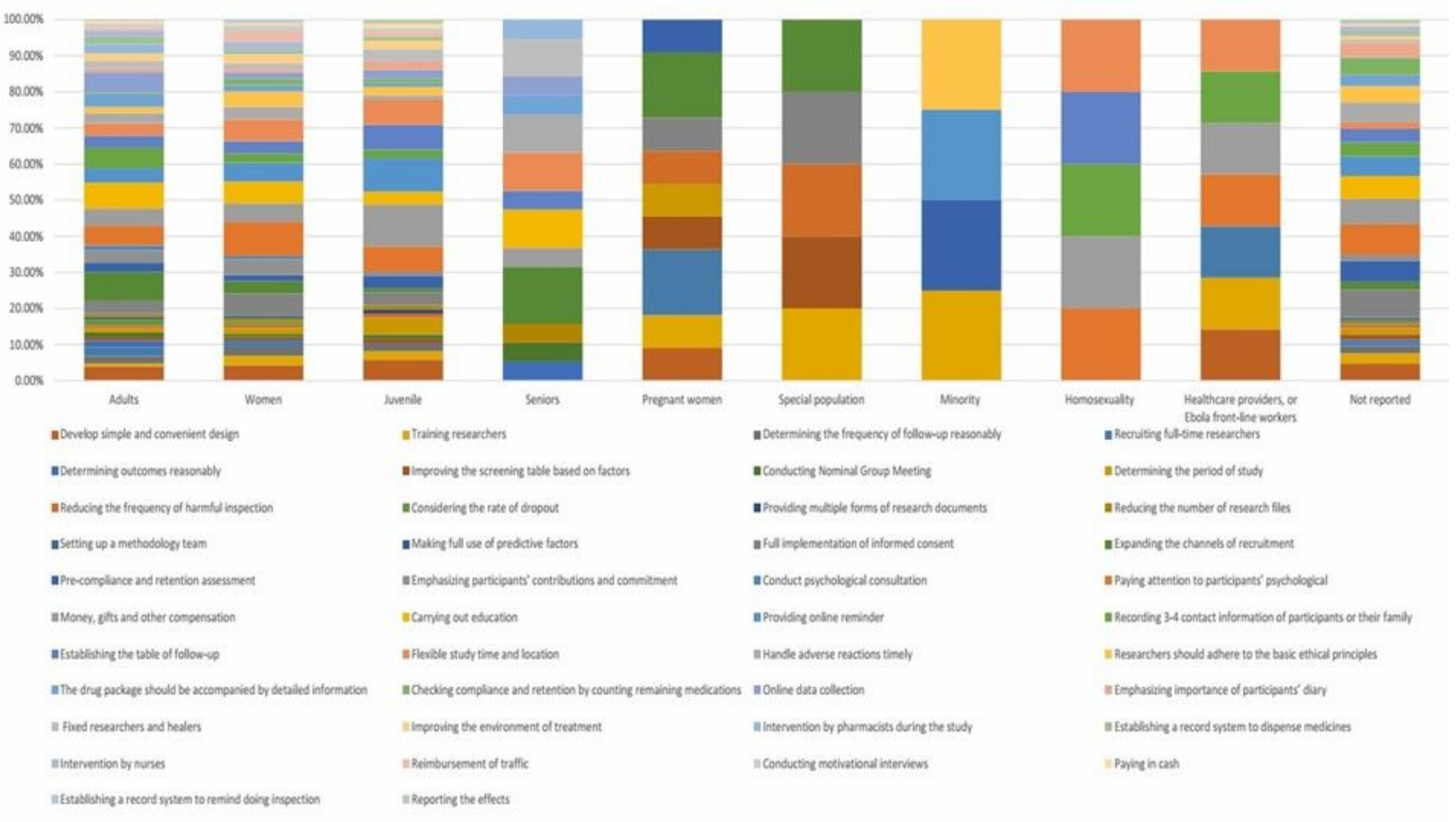

Figure 6

The improvement strategies in different populations

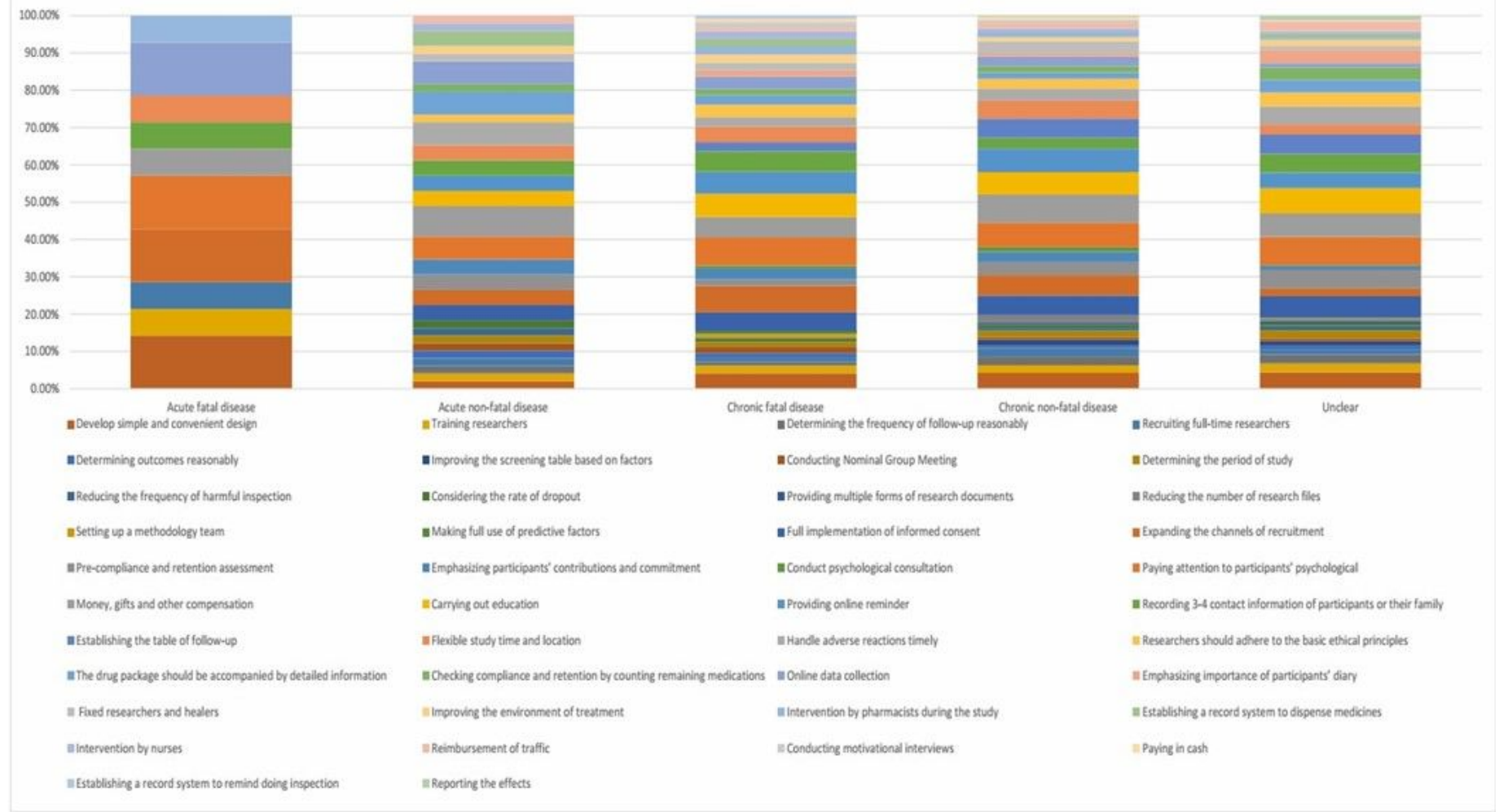

Figure 7

The improvement strategies in different diseases

\section{Supplementary Files}

This is a list of supplementary files associated with this preprint. Click to download.

- Appendixfigure1.pdf 
- Appendixfigure2.pdf

- Appendixfigure3.pdf

- Appendixfigure4.pdf

- Appendixfigure5.pdf

- Appendixfigure6.pdf

- Appendixfigure7.pdf

- Appendixfigure8.pdf

- Appendixfigure10.pdf

- Appendixfigure9.pdf

- Appendix2theextractiontableofincludedstudies.xIsx

- PRISMAScRFillableChecklist1.docx 